GEOLOGICAL SURVEY CIRCULAR 193

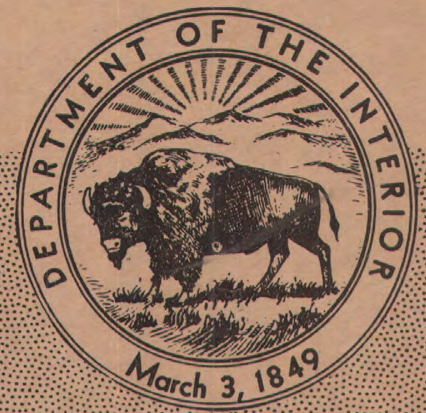

\title{
THE BAUXITE DEPOSITS OF FLOYD BARTOW, AND POLK COUNTIES NORTHWEST GEORGIA
}

By W. S. White and N. M. Denson

$$
\begin{aligned}
& \text { U.S. Goological Survey } \\
& \text { Ground Water Branch } \\
& \text { C.hrmbus, Ohio } \\
& \text { OFFICE COPY }
\end{aligned}
$$




\author{
UNITED STATES DEPARTMENT OF THE INTERIOR \\ Oscar L. Chapman, Secretary \\ GEOLOGICAL SURVEY \\ W. E. Wrather, Director
}

GEOLOGICAL SURVEY CIRCULAR 193

\title{
THE BAUXITE DEPOSITS OF FLOYD, BARTOW, AND POLK COUNTIES NORTHWEST GEORGIA
}

By W. S. White and N. M. Denson

Washington, D. C., 1952

Free on application to the Geological Survey, Washington 25, D. C. 



\section{CONTENTS}

Page

Abstract ....................... 1

Introduction $\ldots \ldots \ldots \ldots \ldots \ldots \ldots \ldots \ldots \ldots \ldots$

Previous work .................... 3

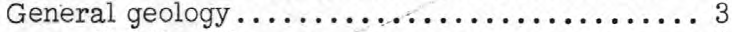

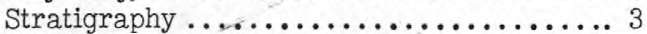

Structure ...................... 5

Bauxite deposits................... 5

History, production, and

reserves................... 5

Geology ........................ 7

Shape and character of deposits............... 7

Stratigraphic position of the deposits ............ 7

Structural position of the deposits............... 7

Altitude of the deposits .........7

Topographic position of the deposits .............. 8

Relation to major land forms................. 8

Proximity to brown iron ores..................... 9

Origin of the bauxite deposits .......... 9

Exploration guides ......................

Concealment ......................10

Restriction of deposits to the

Knox group ...................10
Exploration guides. --Continued

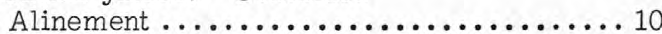

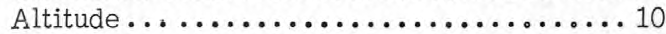

Regional topographic setting $\ldots \ldots \ldots \ldots \ldots 11$

Size of deposits .................... 11

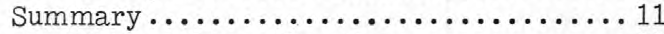

Recommendations for exploration...........11

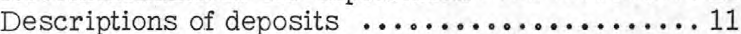

Hermitage district ................ 12 Section 3, district $5 \ldots \ldots \ldots \ldots \ldots 12$

Section 3, district $15 \ldots \ldots \ldots \ldots . . .12$

Section 3 , district $16 \ldots \ldots \ldots \ldots \ldots 13$

Section 3, district $23 \ldots \ldots \ldots \ldots \ldots 16$

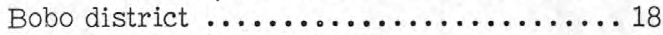
Section 3, district $22 \ldots \ldots \ldots \ldots \ldots 18$

Section 4 , district $3 \ldots \ldots \ldots \ldots \ldots 20$

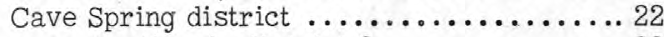
Section 4, district $2 \ldots \ldots \ldots \ldots .22$

Section 4 , district $3 \ldots \ldots \ldots \ldots 22$

Section 4, district $16 \ldots \ldots \ldots \ldots 23$

Scattered deposits of southeastern

Floyd County and southwestern

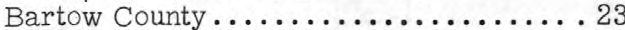

Section 3, district $17 \ldots \ldots \ldots 23$

Section 3, district $22 \ldots \ldots \ldots \ldots 23$

Section 3, district $23 \ldots \ldots \ldots \ldots .24$

Gazetteer of named deposits ............. 25

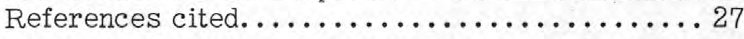

\section{ILLUSTRATIONS}

Page

Plate 1. Geologic map of the Hermitage bauxite district, Georgia $\ldots \ldots \ldots \ldots \ldots \ldots \ldots \ldots \ldots \ldots . .$. In pocket

2. Geologic map of the Cave Spring bauxite district $\ldots \ldots \ldots \ldots \ldots \ldots \ldots \ldots \ldots \ldots \ldots \ldots \ldots$ In pocket

3. Bauxite deposits of southeastern Floyd and southwestern Bartow Counties .............. In pocket

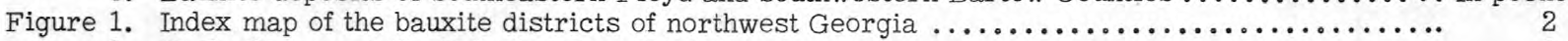

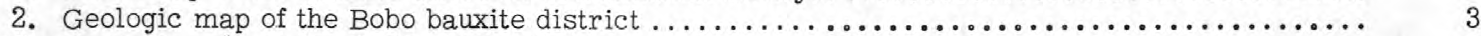

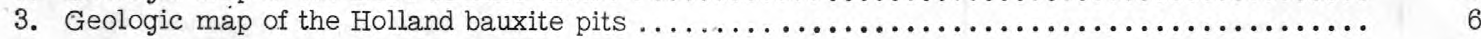

TABLES

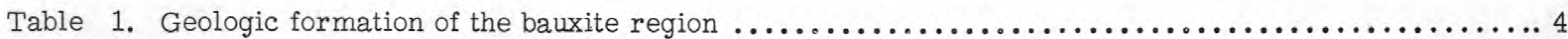

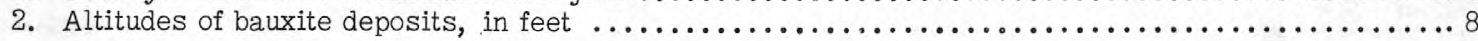





\section{THE BAUXITE DEPOSITS OF FLOYD, BARTOW, AND POLK COUNTIES NORTHWEST GEORGIA}

\section{ABSTRACT}

Most of the bauxite deposits of northwest Georgia are in the Hermitage, Bobo, and Cave Spring districts in Floyd, Bartow, and Polk Counties. The region has produced in the neighborhood of 400,000 tons of bauxite from about 65 small mines, but the known reserves of high grade bauxite are very small. The region was studied in 1942-43 as part of the strategic minerals program of the U. S. Geological Survey.

The rocks of the region include shale and quartzite of Cambrian age, and the Knox group of Cambrian and Ordovician age. In the Hermitage district, a broad plateau underlain by nearly flat-lying strata of the Knox group is locally interrupted by two anticlinal valleys, and the rocks are only slightly disturbed by faults. In the Bobo and Cave Spring districts, the rocks are cut by a series of reverse faults that strike nearly north and dip steeply east.

The bauxite occurs as pods or pockets in the residual clay derived from the dolomite of the Knox group. Individual pockets range up to $200 \mathrm{ft}$ across and at least $120 \mathrm{ft}$ in depth. Most of them have roughly the shape of vertical cylinders or inverted cones, but a few resemble vertical veins and others are blanket deposits. The bauxite is generally separated from the residual clay by an envelope of kaolinitic fire clay.

Of the various theories that have been proposed for the origin of the deposits, the following, proposed by Bridge, seems most reasonable. Kaolin, transported by streams draining from the Piedmont, accumulated.in sink holes and was there maturely weathered during Eocene time to form the bauxite.

Most of the deposits that have surface outcrops have probably been found. Undiscovered deposits should be sought, therefore, primarily in places where surficial debris is now accumulating rather than being eroded. The following characteristics of the deposits themselves suggest useful guides to areas favorable for new discovery. (1) All but one of the known deposits lie within areas underlain by the Knox group. (2) The deposits tend to lie on lines, some of which are known to be the traces of faults. Lines that pass through several neighboring bauxite or iron ore deposits, or follow faults, or are characterized by topographic features that suggest weakness of the underlying rocks may be regarded as favorable for prospecting. (3) The most favorable areas are above $800 \mathrm{ft}$ in altitude. (4) In plateau areas, the dip-slope side of high cuesta-like plateau rims are most favorable for the preservation of bauxite deposits. Areas that satisfy the above conditions and are therefore regarded as favorable for exploration are indicated on the geologic maps.

\section{INTRODUCTION}

The Hermitage, Bobo, and Cave Spring bauxite districts, once important producers of the ore of aluminum, include parts of Floyd, Bartow, and Polk Counties, Georgia. Figure 1 shows the location of these districts, and of an area east of the Bobo district and south of the Hermitage district that also contains a few deposits. Plates 1-3 and figure 2 are geologic maps of these areas.

The bauxite region was studied in 1942 and early 1943 as part of the strategic minerals program of the U. S. Geological Survey. The immediate purpose of the study was to locate areas favorable for prospecting by the Bureau of Mines. Although a number of favorable areas were revealed, the more promising possibilities in districts on the Atlantic Coastal Plain and in Arkansas made intensive exploration in northwestern Georgia less attractive. In 1943 , a little hand augering was done on known prospects (Lewiecki, 1949), but none of the promising areas for wildcat exploration were tested.

The present renewed demand for bauxite, however, may considerably increase the value of the work that was done. Although this report is based on unpublished reports written a number of years ago, and may be very much out of date with respect to subsequent developments at some deposits in the district, it should, none the less, prove of some value as a starting point for any further investigations or explorations in the district. The report is intended to be primarily a guide to the known deposits of the district, and a vehicle for designating the areas that the writers hold most favorable for exploration.

The investigation was carried out under the general direction of Josiah Bridge of the U. S. Geological Survey, who, with Preston E. Cloud, Jr., of the Survey, frequently joined the writers in the field in consultation on various problems. The senior author spent eight months in field work, and the junior author about ten. James Morris assisted the writers for a month. The senior author prepared the maps and report, and is much indebted to Miss Elizabeth C. Fischer of The Geological Survey for advice and assistance in the process.

Thanks are due to many people for information on the location, character, and production of certain deposits. The following have been particularly helpful: Messrs. J. T. Watters, W. T. Watters, and Joe Lowrie of Hermitage, Mr. James Adams of Adairsville, Messrs. Robert Mumford and William Torbert of Cartersville, and Mr. J. Hebble of Rome. The writers are especially grateful to Capt. Garland Peyton, State Geologist, for his continued interest 


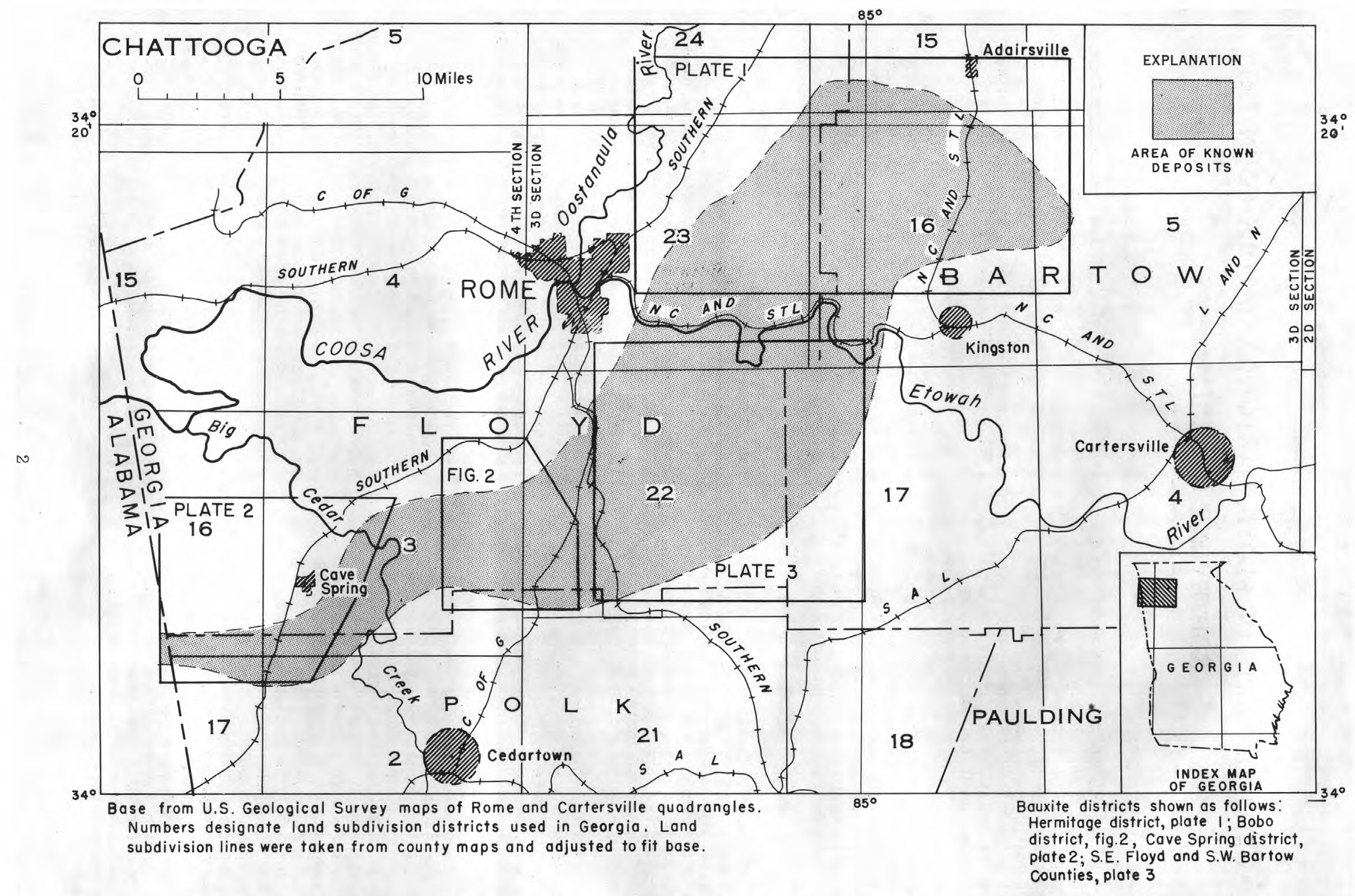

Figure 1. --Index map of the bauxite districts of northwest Georgia. 


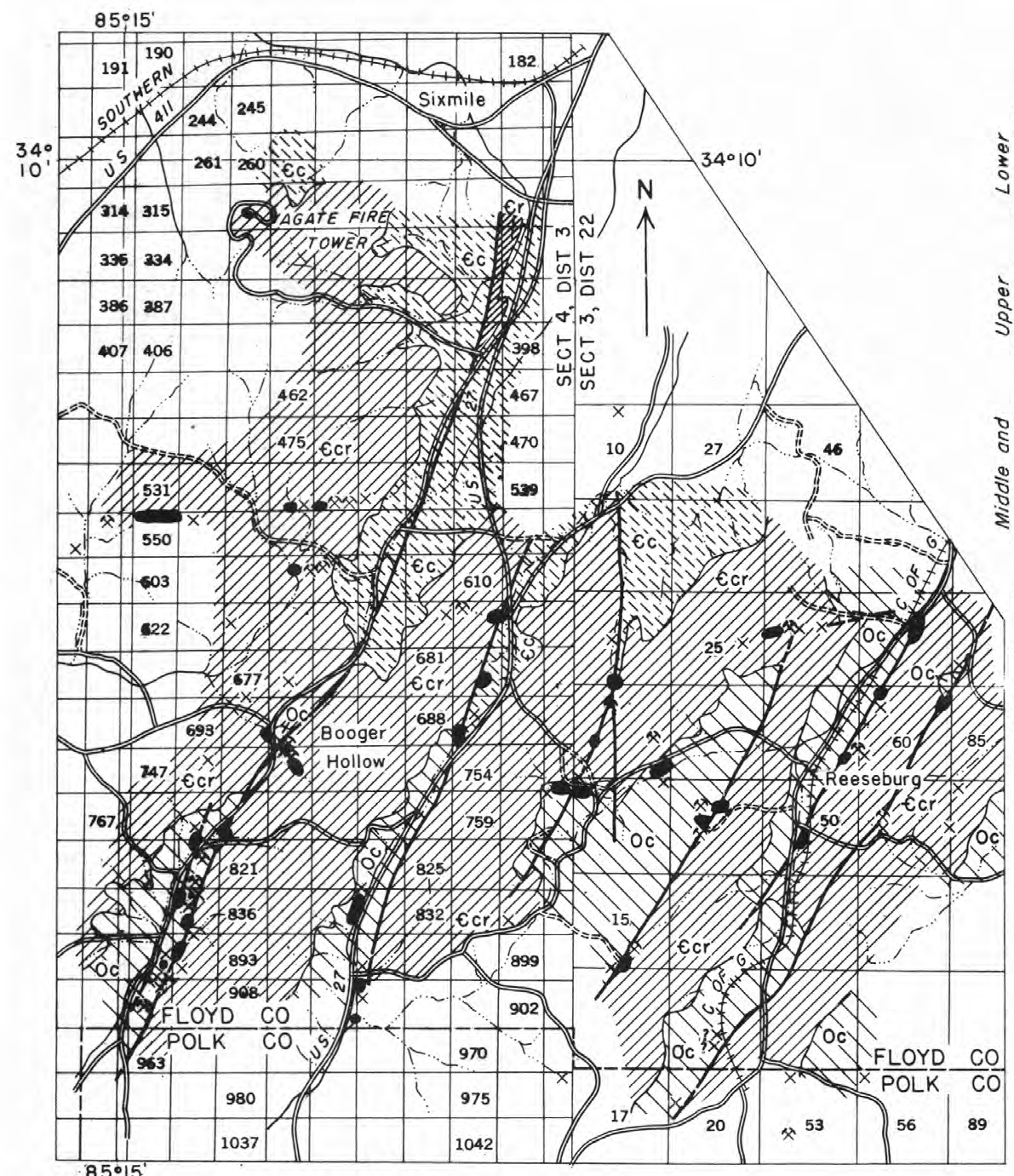

Base from uncontrolled photomosaic of the Production and Marketing Administration
Geology by W. S. White and N. M. Denson, 1942

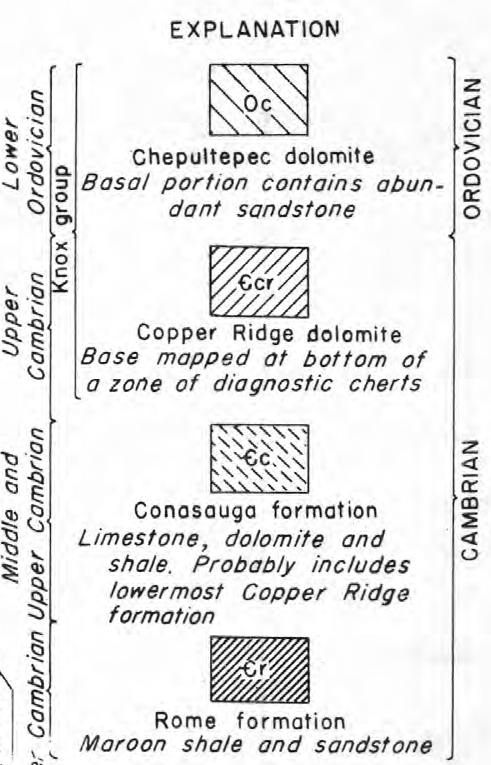

Maroon shale and sandstone

Geologic boundary

Fault, dashed where approximately located

x Bauxite mine $x$

Prospect showing bauxite or bouxitic clay

56

Land lot number

Lot lines were plotted from aerial photographs. Fairly accurate throughout the area

Area favorable for discovery of concealed bauxite deposits

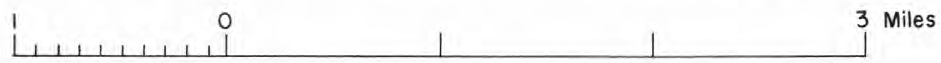

Figure 2.--Geologic map of the Bobo bauxite district, Georgia.

in the investigation and for placing material in the files of the State Survey at their disposal. A number of the deposits in the region were explored as a relief measure during the $1930^{\prime} \mathrm{s}$, and this work was done under the direction of the State Survey. The detailed records of this exploration have proved most helpful.

\section{PREVIOUS WORK}

Hayes (1895, 1902) and Watson (1904) have made the most complete studies of the geology and bauxite deposits of the area. Watson's report, in particular, has proved of great value for its detailed descriptions of many of the individual deposits. Exposures available to Hayes and Watson make their descriptions of the mode of occurrence of the bauxite far more valuable than anything that could be written solely on the basis of present exposures.
Others who have briefly described the district or certain mines are Spencer (1893), McCallie (1910, pp. 39-49), Shearer (1917, pp. 325-329), and Butts and Gildersleeve (1948, particularly pp. 86-89).

\section{GENERAL GEOLOGY}

\section{Stratigraphy}

The rocks of the bauxite region are dolomites, limestones, shales, and quartzites of Cambrian and Ordovician age. The stratigraphic units distinguished in the area are shown in table 1. The bauxite deposits, with one exception, are all found within areas underlain by the Knox group, and only this unit need be considered in detail. 
Table 1.--Geologic formations of the bauxite region

\begin{tabular}{|c|c|c|c|c|}
\hline Age & & Formation & $\begin{array}{l}\text { Thickness } \\
\text { (feet) }\end{array}$ & Lithology \\
\hline $\begin{array}{l}\text { Early } \\
\text { Ordovician. } \\
\text { Late } \\
\quad \text { Cambrian. }\end{array}$ & 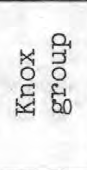 & $\begin{array}{l}\text { Chepultepec } \\
\text { dolomite. } \\
\text { Copper Ridge } \\
\text { dolomite. }\end{array}$ & 500 & $\begin{array}{l}\text { Dolomite. } \\
\text { Dolomite. }\end{array}$ \\
\hline $\begin{array}{l}\text { Middle and Late } \\
\text { Cambrian. }\end{array}$ & & $\begin{array}{l}\text { Conasauga } \\
\text { formation. }\end{array}$ & 2000 & $\begin{array}{l}\text { Dominantly soft, thinly laminated, buff- } \\
\text { colored shale, with beds and lenses of } \\
\text { limestone. Minor dolomite near top. } \\
\text { Prominent shale members distinguished } \\
\text { in plate } 1 \text {. }\end{array}$ \\
\hline \multirow[t]{3}{*}{$\begin{array}{l}\text { Early } \\
\quad \text { Cambrian. }\end{array}$} & & $\begin{array}{l}\text { Rome } \\
\text { formation. }\end{array}$ & 2000 & Red and green shale and sandstone. \\
\hline & & $\begin{array}{l}\text { Shady } \\
\text { dolomite. }\end{array}$ & (?) & $\begin{array}{l}\text { The Shady has been mapped in nearby } \\
\text { areas, but was not recognized in the } \\
\text { bauxite districts. }\end{array}$ \\
\hline & & $\begin{array}{l}\text { Weisner } \\
\text { quartzite. }\end{array}$ & 2000 & $\begin{array}{l}\text { Quartzite and quartzitic conglomerate, } \\
\text { minor shale. }\end{array}$ \\
\hline
\end{tabular}

aAs given by Butts (Butts and Gildersleeve, 1948, Geologic Map of northwest Georgia).

The lowermost two formations of the Knox group in this region are the Copper Ridge and Chepultepec dolomites (Butts and Gildersleeve, 1948, pp. 16-18). Both formations are very poorly exposed because of their deep weathering and fewer than 20 outcrops were seen in the areas mapped. All stratigraphic subdivision, therefore, is based on the areal distribution of fossiliferous or otherwise distinctive chert and sandstone fragments in the residual clay.

At the base of the Copper Ridge dolomite, there is generally a zone of dense massive chert that breaks out in large fragments. Near the top of this zone, typically at elevations 50 to $150 \mathrm{ft}$ above the nearest shale of the Conasauga formation on steep slopes, there are abundant fragments of porous chert, some spongelike and others rather dark with cavities like large worm-holes scattered through them. Some of the more porous cherts contain Copper Ridge fossils.

Above the zone of porous cherts in the Copper Ridge dolomite is a zone, over $200 \mathrm{ft}$ thick, in which the cherts are of various types, none particularly distinctive or characteristic.

The next succeeding zone here assigned to the Chepultepec dolomite, is characterized by platy fragments of indurated sandstone that range in thickness from an inch to about a foot. The zone seems to be a stratigraphic unit a few tens of feet thick. Even where it sheds abundant float, this sandstone does not crop out; it probably occurs as interbeds in the dolomite and breaks up when the carbonate beds are dissolved. The sandstone zone is found throughout the district and seems to be relatively continuous. There are small gaps in the continuity of the float and a number of places where the zone seems to be represented by very few sandstone fragments; but with due allowance for the vagaries of float in general this might, perhaps, be expected of a perfectly continuous stratigraphic unit.
At least $250 \mathrm{ft}$ stratigraphically above the sandstone zone, and perhaps still higher if allowance is made for slump and compaction in the residual clays, there are locally porous cherts with Chepultepec fossils. The cherts above the sandstone and below the porous cherts are rather nondescript, like those below the sandstone. Locally there are abundant black to white concretionary cherts, shaped like thick pancakes, in the zone above the sandstone, but as these are also found locally in small numbers below the sandstone, they have little value in stratigraphic subdivision.

The boundary between the Copper Ridge and Chepultepec dolomites has here been placed arbitrarily at the base of the zone of sandstone. This zone is a useful and satisfactory marker for mapping purposes, and generally seems to be about half way between fossiliferous rocks of each formation. More precise paleontologic zoning may, of course, place the boundary higher or lower.

No reliable estimate of the actual thicknesses of the subdivisions of the Knox group can be made without more data on the thickness of the residual clay at numerous places and on the amount of compaction that takes place on removal of carbonate minerals. The ratio of original dolomite to residual clay may well be more than 10 to 1 on the basis of the amount of impurity in the dolomite (see analyses in Watson, 1904 , p. 35), and the thickness of the residual clay is at least 50 or $60 \mathrm{ft}$ in many high cut banks and roadcuts in the region. The traces of geologic boundaries in the Hermitage district (pl. 1) indicate that the dips are mostly rather gentle. With no allowance for compaction and subsidence, one may estimate that Chepultepec fossils on a hilltop $11 / 2$ miles southwest of Halls Station are 500-600 ft stratigraphically above the top of the Conasauga formation, and that the sandstone is generally 250-300 ft above the Conasauga. The true stratigraphic distances must be somewhat greater. 
The Knox group forms plateaus where the dip is gentle and ridges where it is steep. The base of the formation generally lies in an escarpment overlooking a valley in the Conasauga formation.

\section{Structure}

The structure of most of the region is simple. In the Hermitage district (pl. 2), the rocks are nearly flat. A broad plateau upheld by the Knox group is interrupted by two broad low anticlines that bring the Conasauga formation to the surface in the north-south valley of Barnsley Creek and the larger valley that extends south from Adairsville. The latter anticline is locally bounded by a fault along its western side. Small inliers of the Conasauga just east of Hermitage reflect a minor upwarp. The rocks of this district are cut by two sets of small faults that have been mapped on the basis of apparent stratigraphic offset. One set strikes north to northeast and probably dips steeply eastward. The east side of each fault has risen with respect to the west. Faults of the second set strike roughly at right angles to those of the first, and probably have essentially vertical dips. They have no uniform direction of offset.

The remainder of the bauxite region (fig. 2, pls. 2, 3) is characterized by a series of fault blocks. The individual slices strike north to north-northeast, and range in width from a half mile to several miles. The bedding in the slices dips gently to fairly steeply east. Each slice seems to be bounded on the west by a reverse fault that raises it several hundred feet stratigraphically with respect to the next slice to the west. Erosion has carved valleys in the shales and left long parallel ridges in those parts of the slices that are underlain by the Knox group.

Small klippen of Weisner quartzite in the southwestern part of the Cave Spring district (pl. 2) are outliers of the overthrust mass of Indian Mountain, which lies just south of the map area (Hayes, 1902).

\section{BAUXITE DEPOSITS}

\section{History, production, and reserves}

The first material identified as bauxite in the United States was found two miles east of Hermitage (pl. 3) about 1883 and announced in 1887. Mining of bauxite began the following year, and Georgia was the leading producer until 1892, when Alabama took the lead. Since the first substantial production of bauxite in Arkansas in 1903, the districts of northwest Georgia have contributed only a small fraction of the nation's total. The pockety nature of the deposits themselves and irregular marketing conditions have caused large fluctuations in the annual production. Most of the bauxite has been used in the manufacture of chemicals.
The following figures for the production of bauxite in northwest Georgia have been published, or may be roughly estimated from published statements:

$\begin{array}{ccc}\text { Year } & \begin{array}{c}\text { Bauxite } \\ \text { (long tons) }\end{array} & \text { Source of data } \\ 1889 & 728 & \text { Phalen (1911). } \\ 1890 & 1,844 & \text { Do. } \\ 1891 & 3,301 & \text { Do. } \\ 1892 & 5,110 & \text { Do. } \\ 1893 & 2,415 & \text { Do. } \\ 1894 & 2,050 & \text { Do. } \\ 1895 & 3,756 & \text { Do. } \\ 1896 & 7,313 & \text { Do. } \\ 1897 & 7,507 & \text { Do. } \\ 1898 & 12,943 & \text { Ingalls (1906). } \\ 1899 & 19,619 & \text { Do. } \\ 1900 & 20,715 & \text { Do. } \\ 1902 & 19,000 & \text { Do. } \\ 1904 & 16,909 & \text { Do. } \\ 1909 & 20,000 & \text { Phalen (1911)a } \\ 1910 & 23,579 & \text { Morse (1923), p. } 72^{b} . \\ 1917 & 15,000 \mathrm{c} & \text { Hill (1921), p. 5 } \\ 1932 & --.- & \text { Julihn (1933). }\end{array}$

aproduction in 1910 is stated to be 16 percent more than in 1909.

Includes first shipments from Coastal Plain, probably very small.

${ }^{c}$ About.

The production of bauxite in northwestern Georgia has not been reported separately for most years since 1900. Only the combined production of Georgia and Alabama is reported in the Mineral Resources of the United States for the years 1900-09. Assuming no drastic shifts in the relative proportion of the combined production that may be assigned to Georgia for these years, the average production may be estimated to be about 18,000 tons per year.

The deposits in the Coastal Plain of Georgia increased in importance after 1910, and only the total Georgia production has been published for the years 1910-1928 (Franke and Trought, 1939). Assuming that production from northwest Georgia decreased uniformly from about 100 percent of the total in 1910 to 28 percent in 1917, to 0 in 1932 , one may derive at least an approximate figure for the total production for this period. Combining these estimates of annual production with the known production of the earlier years, one arrives at a figure of about 400,000 tons for the total production of bauxite during the period 1889-1932. Production since 1932 has been small.

The figure of 400,000 tons thus estimated for the total production of the northwest Georgia field agrees very well with a crude estimate of slightly less than 500, 000 tons made by the writers on the basis of the size of the pits and dumps. According to this estimate, about 45 percent of the total came from three large mines, the Julia, Watters, and Booger Hollow mines. Over 20 percent came from five of the Holland group of pits (fig. 3). About 15 percent came from six other mines, the Hampton, Curtis, Terry-Shaw, Maddox, Hawkins, and Fat John, and the remaining 20 percent from about 50 small mines, including a few small mines outside the area described here. 

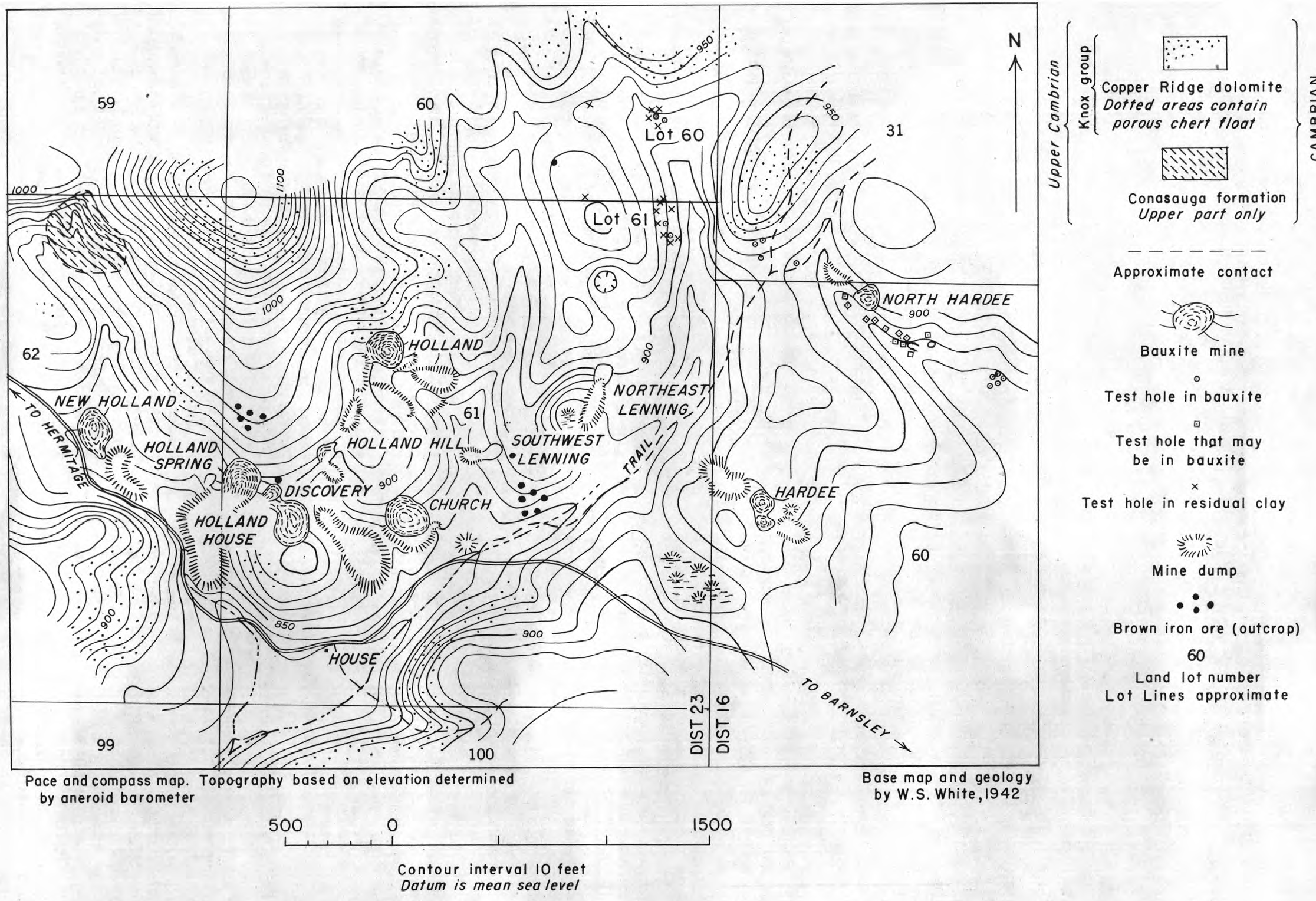

$------$

Approximate contact

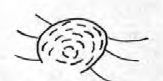

Bauxite mine

。

Test hole in bauxite

$$
\square
$$

Test hole that may

be in bauxite

$$
x
$$

Test hole in residual clay

$$
\begin{gathered}
\frac{111 ! \prime \prime}{\overline{5}} \\
\text { Mine dump }
\end{gathered}
$$

Brown iron ore (outcrop)

60

Land lot number

Lot Lines approximate

Figure 3. --Geologic map of the Holland bauxite pits, Georgia. 
Known reserves of high-grade bauxite are very small. They consist mostly of bauxite left in the bottoms of abandoned mines, and recovery is made costly by the slumping of pit walls. There are probably over 300, 000 tons of very low-grade siliceous and ferruginous bauxite and bauxitic clay adjacent to old mines and in unworked prospects.

The chances for discovery of new deposits are discussed below.

\section{Geology}

The character of the bauxite deposits and of the materials within and surrounding them have been described in considerable detail by Hayes (1895) and Watson (1904). The following brief account of the geology of the deposits emphasizes those characteristics that seem to bear most closely on the problem of prospecting for new deposits, and the reader is referred to the reports of Hayes and Watson for more complete information on such subjects as the chemical composition of the bauxite and associated materials, and the textural varieties of the bauxite. Veatch (1909, pp. 261-274) describes those features of the bauxite and associated clays that have a bearing on the clay industry.

\section{Shape and character of deposits}

The bauxite occurs in pockets in the residual clay and chert derived from the weathering of the underlying dolomitic rocks. The pockets range in size from a few feet to at least $200 \mathrm{ft}$ across, and up to at least $120 \mathrm{ft}$ in depth. A majority seem to be oval or circular pipe-like bodies, with vertical walls, or funnel-shaped bodies whose walls dip steeply inward like an inverted cone.

Less commonly, the deposits more closely resemble steeply dipping or vertical veins. This type, best exemplified by the Curtis and Conneseena deposits (see descriptions below), may be several hundred yards in length. These vein-like deposits generally consist of a line of individual pods or lenses, each elongate parallel to the line of the whole, and do not represent a single continuous mass of bauxite. The pods range in width from a few feet to $50 \mathrm{ft}$ or more, and there may or may not be a connecting mass of bauxite between adjacent pods.

A'few deposits, like the Terry-Shaw, Mary, and Henry, seem to be more like blankets, having far greater horizontal extent than their probable vertical depth. Such deposits may show a layering of the bauxitic material, or of bauxite and clay, and this layering generally dips in the direction of the present topographic slope.

So far as can be seen in the present poor exposures, the bauxite is typically separated from the surrounding residual clay by an envelope of chertfree plastic clay. This clay is probably kaolinitic at most or all places (Watson, 1904, pp. 38-40; Veatch, 1909, pp. 261-262; Bridge, 1950, pp. 186191), but, as no study was made of its mineralogy, it will be referred to here as fire clay. Bauxite is rarely seen in direct contact with cherty residual clay in pit walls. In the vein-like Curtis deposit, the bauxite seems to lie in the centers of large pods; where the vein is wide, fire clay forms an envelope around the bauxite, and in at least one place where the vein is narrow, it consists entirely of clay. In addition to an envelope of fire clay, most deposits also contain many veins and horses of clay within the bauxite mass itself (Watson, 1904, p. 38, and notes on many individual deposits, pp. 60-118; Veatch, 1909, p. 262).

The bauxite deposits and their envelopes of clay are generally covered by at least several feet of detrital clay and chert that have washed or slumped down over them. As most of the deposits have been discovered from bauxite outcrops or float, however, it may be presumed that the hard bauxite commonly protrudes through this cover in places, or at least breaks off in pieces that become incorporated with and work their way to the surface of the debris.

Stratigraphic position of the deposits

With the exception of the Bradshaw deposit, which seems to be in an area underlain by the Conasauga formation, all the deposits lie within or so close to areas underlain by the dolomite of the Knox group that all formations other than those of the Knox group may well be ignored in the search for new deposits. No particular stratigraphic interval or intervals within the Knox group seem to be notably more favorable for the occurrence of bauxite deposits than any other.

\section{Structural position of the deposits}

Many of the deposits in the region show a remarkable tendency to.be on lines that pass through two or more neighboring deposits. Such alinements are conspicuous in the southwestern part of the Bobo district (fig. 2) and in the area 1-2 miles due south of Hermitage (pl. 1); less striking examples can be found in many other places. The more notably veinlike deposits described above represent an extreme manifestation of alinement. As noted by Hayes (1895, p. 589) some of these lines lie parallel to and on or very close to known faults, a relation best shown in the Bobo (fig. 2) and Cave Spring (pl. 2) districts. The detailed mapping done in connection with the present investigation shows a similar coincidence of faults with lines of bauxite deposits in parts of the Hermitage district (pl. 1).

The writers conclude that faults are the loci of most of the bauxite deposits for the following reasons: the presence of bauxite deposits along or immediately adjacent to many known faults, the vein-like form of some deposits, and the conspicuous alinement of three or more deposits at many places. Faults are not shown on the maps, however, except where there is evidence of stratigraphic offset, and a large number of faults may have been missed because of the uncertainties of mapping residual materials.

\section{Altitude of the deposits}

The altitude of the top of most of the deposits was carefully determined by means of an altimeter in areas that are not covered by accurate topographic maps. These altitudes are given in the descriptions of individual deposits. The deposits range from 645 to $1,110 \mathrm{ft}$ above sea level. The median and average 
altitudes are about $885 \mathrm{ft} ; 50$ percent of the deposits lie between 835 and $935 \mathrm{ft}$ above sea level, and 90 percent between 770 and 1,000 ft. Data for the various districts are tabulated in table 2. The median altitudes show the most uniform trend, a gradual descent from northeast to southwest.

The high frequency of deposits close to $900 \mathrm{ft}$ above sea level has been held by Hayes (1895), Watson (1904), and others, and most recently by Bridge (1950, pp. 191-193), to reflect a relationship to an Eocene land.surface whose temporary base level lay, in this region, close to $950 \mathrm{ft}$ above the present sea level. Discovery of Eocene fossils in lignite in the Booger Hollow deposit (Bridge, 1950, p. 194) suggests a correlation with the Eocene deposits of the Coastal Plain. The present wide range in altitude of the deposits, 645-1, $110 \mathrm{ft}$, is attributed to deposition of the bauxite or its parent material in Eocene sink holes, or to subsidence of the bauxite into sink holes at some time since the Eocene (Bridge, 1950, p. 197).

As an explanation of the abundance of deposits near $900 \mathrm{ft}$, this theory needs to be modified. Bridge (1950, pp. 195-197) has shown that the parent material of the bauxite was probably brought into the area by streams flowing from the Piedmont. The bed of at least one such stream must have lain at or above the highest deposit in each district; if the land surface was fairly level, its erosional remnants must now lie well above 1,050 ft in the Hermitage district, at least. The present abundance of deposits slightly below $900 \mathrm{ft}$ cannot be due to deposition of parent material on a surface that now lies near $950 \mathrm{ft}$, and there must be some other reason for the concentration.

The writers believe that the number of deposits above $1,050 \mathrm{ft}$ is small primarily because the total land surface above this altitude is small. The number of deposits below $750 \mathrm{ft}$ is believed to be small because relatively few deposits can survive the requisite amount of slumping or erosional lowering of the land surface. The average altitude of $885 \mathrm{ft}$ would seem, empirically, to be high enough to permit a good chance of survival, yet not so high that the percentage of total land surface is very small.

The number of deposits per unit area should decrease from a maximum somewhere above $1,110 \mathrm{ft}$ of altitude to a very small ratio below $700 \mathrm{ft}$, if the writers' view is correct. Brief inspection of the old small-scale topographic maps is sufficient to show that the number of deposits per unit area decreases rapidly below $800 \mathrm{ft}$, but more-detailed topographic maps are needed for most of the region before the concentration can be determined at higher altitudes. In the eastern part of the Hermitage district, for which a detailed topographic map (Adairsville quadrangle) is available, the number of deposits per unit area seems to be fairly constant for various altitudes above $800 \mathrm{ft}$; a larger sample is needed, however, before one can obtain reliable figures for the number of deposits per unit area over the whole range of altitudes involved.

\section{Topographic position of the deposits}

Bauxite deposits are found in all conceivable topographic positions, from the tops of hills and ridges to the bottoms of broad valleys. A majority lie in places that suggest weakness of the underlying rocks, such as saddles, the inner edges of benches, the base of steep slopes, and forks in ravines.

\section{Relation to major land forms}

In the Hermitage district (pl. 1), a majority of the deposits lie on the dip-slope side of the high cuesta-like ridges that border the dolomite plateaus. Large deposits are most commonly found at altitudes 50-150 ft below the level of the crest line, and at distances of a quarter of a mile to a mile from the crest. This empirical correlation with major land forms might reflect either conditions of origin or conditions that lead to the preservation of bauxite deposits. As the bauxite itself is ancient, and was probably formed on or near a surface of very low relief, present major topographic features are probably related only remotely, if at all, to the conditions of origin of the deposits. The intensity and kind of erosion that has sculptured the present topography, however, must have profoundly influenced the chances of preservation of deposits.

If the land at any point has been lowered entirely by solution of dolomite since Eocene time, anything present on the Eocene surface should still be present on the modern surface, except insofar as it may have been modified by weathering and soil processes. The depth of the residual mantle at such a point should be approximately equal to the depth of the mantle in Eocene time plus one tenth of the thickness of the

Table 2.--Altitudes of bauxite deposits, in feet

\begin{tabular}{|c|c|c|c|c|c|c|}
\hline District & Highest & Median & Lowest & $\begin{array}{c}\text { Highest } \\
25 \text { percent } \\
\text { above }\end{array}$ & $\begin{array}{c}\text { Lowest } \\
25 \text { percent } \\
\text { below }\end{array}$ & Average \\
\hline $\begin{array}{l}\text { Hermitage east of } \\
\text { Adairsville }\end{array}$ & 1,050 & 935 & 865 & 990 & 915 & 949 \\
\hline $\begin{array}{l}\text { Hermitage west of } \\
\text { Adairsville }\end{array}$ & 1,110 & 910 & 695 & 970 & 840 & 906 \\
\hline SE. Floyd and SW. & & & & & & \\
\hline $\begin{array}{l}\text { Bartow Counties } \\
\text { Bobo }\end{array}$ & $\begin{array}{l}920 \\
980\end{array}$ & $\begin{array}{l}885 \\
860\end{array}$ & $\begin{array}{l}645 \\
785\end{array}$ & $\begin{array}{l}900 \\
900\end{array}$ & $\begin{array}{l}850 \\
835\end{array}$ & $\begin{array}{l}851 \\
866\end{array}$ \\
\hline Cave Spring----------- & 945 & 855 & 750 & 920 & 815 & 861 \\
\hline Total & 1,110 & 885 & 645 & 935 & 835 & 886 \\
\hline
\end{tabular}


dolomite that has been dissolved since Eocene time, assuming 10 percent insolubles in the dolomite.

In most places, on the other hand, large or small amounts of the mantle formed before, during, and since the Eocene will have been removed by surface erosion, The more nearly this surface erosion has been able to remove the insoluble mantle, as fast as it formed, the thinner will be the mantle now and the younger will be the residuum exposed at the top of the mantle.

It follows from the above that, for points at a similar altitude, materials deposited in pockets on an ancient surface. have the greatest chance of preservation in places that now have the deepest residual mantle. Places with the deepest mantle, in turn, would be sought where one might expect solution to have been most responsible and surface erosion least responsible for lowering the land surface. Herein may lie the explanation for the apparent distribution of bauxite deposits on the dolomite plateaus.

As noted above, most of the major deposits lie on the dip-slope side of the cuesta-like plateau rims, generally within a mile of the scarp that bounds the plateau. The base of the scarp is considerably lower, at most places, than the lowest elevations on the plateaus. The zone of actively circulating ground water is presumably deepest at any time, therefore, just behind the scarp, and becomes thinner towards the center of the plateau. Insofar as a deep active circulation of ground water favors solution--the formation of caves and sinks, and subterranean drainage at the expense of surface drainage--bauxite deposits should be expected where they are, in fact, found in greatest abundance, namely, near the plateau rims, and particularly their highest parts. The scarp sides of the marginal cuestas are being actively eroded, for the most part, and on this account would be expected to be unfavorable for the preservation of ancient deposits.

The explanation offered here would be immeasurably strengthened by a demonstration that the areas in which bauxite is found are, indeed, most commonly areas of deeper-than-average residual mantle, but unfortunately no critical data are readily available on the depth of overburden. It should be pointed out, also, that a few unusual deposits, like the Hawkins mine, lie at low altitudes, far removed from plateau rims; so even if the above explanation is generally correct, some exceptional conditions or characteristics may locally preserve deposits in places that would theoretically be regarded as unfavorable.

In most of the Bobo and Cave Spring districts (fig. 2, pl. 2), the rocks dip relatively steeply, and the ridges are hogbacks rather than cuestas. There are few prominent scarps like those of the Hermitage district, and both sides of most ridges have comparable slopes; these slopes are generally shorter and much less steep than the scarps of the Hermitage district. The bauxite deposits lie on the flanks and tops of the hogback ridges, and on the floors of the intervening valleys. If regional topographic controls exist, they were not detected.

\section{Proximity to brown iron ores}

Proximity to deposits of brown iron ore is characteristic of the bauxite deposits. This is strikingly shown on the Economic Geology sheet of the Rome Folio (Hayes, 1902). Brown ore is typically more abundant along lines of bauxite deposits than at either side of such lines. Although abundant brown iron ore does not necessarily indicate proximity to bauxite deposits, a great many bauxite mines and prospects have pockets of brown ore within one or two hundred feet.

\section{Origin of the bauxite deposits}

The origin of the bauxite deposits involves many factors that go far beyond the scope of this investigation, and the reader is referred to the work of Spencer (1893), Hayes (1895), Watson (1904), Adams (1923), and Bridge (1950) for detailed accounts of the various theories that have been proposed. Only a brief recapitulation is attempted here.

Spencer (1893, pp. 225-226) suggested that certain layers within the dolomite itself might contain more highly aluminous impurities than the average, and that on solution and removal of carbonate, the aluminous constituents would be concentrated to form the bauxite deposits.

Hayes (1895), followed by Watson (1904), believed that an artesian circulation oxidized pyrite in the Conasauga shale, and that the resulting sulfuric acid leached alumina from the shale and redeposited it, after rising to the surface through cracks and fissures in the overlying dolomite of the Knox group. The depth of the required circulation, the scarcity of pyrite in the shale of the Conasauga formation, and the age of the deposits oppose this theory; the similar age of the deposits in the area of Paleozoic rocks and on the Coastal Plain must be regarded as pure coincidence, if those of northwest Georgia are due to an artesian circulation and unrelated to climate.

Adams (1923) suggested that the deposits were formed by mature weathering of kaolin in sink holes. Bridge (1950) has elaborated this theory in proposing that the kaolin was derived from the Piedmont area to the east in much the same manner and perhaps at the same time as was the sedimentary kaolin of the Coastal Plain, and that the trapping of this kaolin in sink holes has led to its preservation in isolated patches. The only modification of this theory suggested by the present investigation concerns the altitude of the surface on which the kaolin was transported. As pointed out in a previous paragraph, remnants of this surface must now lie considerably above $1,050 \mathrm{ft}$, rather than near $950 \mathrm{ft}$.

In connection with geologic characteristics of the deposits that are of importance to prospecting, it should be noted that structural control of the location of bauxite deposits might be similar whether the deposits are due to ascending solutions or to deposition in sink holes. Faults could form the channelways for ascending waters or, conversely, lead to the formation of sink holes by providing channelways for near-surface groundwater movement. In either event, deposits 
might tend to form along the line of faults or persistent fissures, and alinement of deposits would be expected.

\section{EXPLORATION GUIDES}

The known deposits of bauxite, with few exceptions, were found from surface showings of ore. In the heyday of bauxite mining, many producers offered rewards to encourage prospectors, and it is safe to assume that few, if any, surface indications have been overlooked within and near the mining districts. It is also improbable that any large new districts remain undiscovered in the area of Paleozoic rocks in general; this would require that many surface showings have gone unrecognized despite the fact that bauxite is most peculiar in appearance. New deposits, therefore, other than a few that may be discovered by accident, will probably be found by systematic exploration with geologic guidance.

\section{Concealment}

Because one may assume that nearly all deposits with surface showings have been discovered, concealment is a factor of first importance in considering the possibility of new discovery in any given area. The bauxite probably formed at or near a surface that lies above the present one, and it seems likely that most large deposits have been uncovered at least partially during the long period of post-Eocene erosion, except possibly in very flat areas. The creep and churning of material in the ordinary slumping that takes place on slopes such as those of the bauxite region would tend to carry at least some small part of the bauxite into the surface debris, where it would be discovered. In general, therefore, a deposit should provide some surface indication except where surface debris is now or has recently been actively accumulating on top of it. Active accumulation would take place least commonly on the upper slopes of hills and ridges and in the bottoms of narrow ravines that are now being cut into the residual clay; it would take place most commonly on the bottoms and lower slopes of broad ravines, valleys, and gentle hollows. Material sliding down from the middle and upper parts of slopes would tend to bury a bauxite deposit near the bottom rather than incorporate it, and the water-borne debris in the aggrading bottoms of broad ravines and valleys would very effectively cover any underlying bauxite. It is significant that a large majority of the known deposits are in places that are unfavorable for concealment, and relatively few are in places that present the optimum chances for concealment.

\section{Restriction of deposits to the Knox group}

There is only one exception to the rule that the deposits occur within areas directly underlain by the Knox group, and the search for new deposits can profitably be restricted to these areas as shown on geologic maps of the region (Hayes, 1902; Butts and Gildersleeve, 1948). A further restriction to specific stratigraphic units within the Knox does not, at present, seem feasible.

\section{Alinement}

The alinement of deposits is their most useful characteristic in terms of pinpointing areas favorable for exploration. That many undiscovered ore bodies may be overlooked by rigid application of the principle of alinement does not detract from its merit in the places where it is applicable. Geologic observations on the deposits that do fall on lines dictate the following general rules for prospecting:

(1) As pointed out by Hayes (1895, p. 597), the line of a known fault is favorable, particularly if deposits have already been found along it.

(2) Where two or three deposits lie fairly close to one another (within a mile or so) on a line that is parallel to known faults in the vicinity, the areas between the deposits and on the projections of the line beyond the deposits are favorable for prospecting.

(3) Where three or more deposits in close proximity lie on a line, the line is probably favorable between and beyond the deposits regardless of its orientation.

(4) The long axis of a markedly elongate bauxite deposit may reliably indicate a line favorable for prospecting. Where two strongly asymmetric deposits are elongate parallel to the same line (e.g. the Red Warrior and Fat John deposits in the Bobo district), the line is definitely worthy of attention.

(5) A line that crosses many points whose topography expresses weakness of the underlying rocks more probably represents a fault than does a line without topographic expression. The most conspicuously alined deposits of the region lie on lines that commonly follow well-defined ravines or topographic benches, and that almost invariably cross ridges at low points (saddles) in the crest line. A line that crosses hilltops, and more commonly crosses ravines than lies along them, probably does not represent a fault.

(6) Outcrops of brown iron ore or fire clay along a line believed to represent a line of weakness should be considered almost as indicative as a bauxite deposit (see Hayes, 1895, p. 597).

It would be easy to exaggerate the significance of alinement, and many lines with no real validity can doubtless be drawn through many groups of deposits. If a line is given greater or less weight in proportion to the number of the above conditions it satisfies, however, the principle should be most useful. The distribution of test holes near many mines shows clearly that operators are aware of its potential usefulness.

\section{Altitude}

The number of deposits per unit area (concentration of deposits) at a given altitude is more significant than the number of deposits at that altitude as a measure of the chances of discovery. By this measure, areas at higher altitude are generally more favorable than those at lower altitude within the area of known deposits as outlined in figure 1. The large number of deposits near $885 \mathrm{ft}$ is believed to be due in part to the large amount of land surface near this altitude and does not mean that areas at higher altitudes are less favorable; they may be more favorable. Areas less than $800 \mathrm{ft}$ above sea level are definitely unfavorable. 
Regional topographic setting

In plateau areas of relatively gentle dip, like the Hermitage district, the dip-slope side of the high cuesta-like ridges that border the plateau seems to be most favorable for the preservation of bauxite deposits. The scarp side is unfavorable. In a general way, areas characterized by moderate relief and slopes are more favorable, both for preservation and concealment, than rugged terrain.

\section{Size of deposits}

The larger the deposit, the more likely it is to have cropped out and been discovered. It is therefore improbable that many truly large deposits, containing in the neighborhood of 100,000 tons, remain hidden in the region. Deposits of the order of 2,000 to 20,000 tons, however, might well be expected.

\section{Summary}

Areas that seem to be most favorable for discovery of new deposits, on the basis of such geologic evidence as has been considered here, should satisfy the following conditions. (1) They should be underlain, below the residual mantle, by carbonate rocks of the Knox group. (2) They should lie on or near the bottoms of broad ravines and valleys, or on the lower slopes of hills, in topographic situations that now favor the accumulation of debris rather than its removal by erosion. (3) They should lie on lines that may be regarded as structurally favorable on the basis of at least one and preferably more of the criteria described above. (4) In plateau areas, like the Hermitage district, they should preferably lie on the dip-slope side of the cuesta-like ridge at the plateau rim. (5) They should be in highland areas in which most of the land surface lies above 800 feet.

Deposits of 2,000-20, 000 tons are not too large to remain hidden within many of the areas that satisfy the above requirement.

\section{RECOMMENDATIONS FOR EXPLORATION}

Specific areas that are considered to be most favorable for exploration for concealed deposits of bauxite are shown on the geologic maps (pls. 1,2; fig. 2). These areas have been chosen almost entirely on the basis of alinement with known deposits and the chance of concealment. Favorable conditions of topography and stratigraphy are generally satisfied.

Exploration for new deposits beyond the limits of the known districts does not, at present, seem worth while. As discussed above, if there were any substantial number of deposits outside the districts, it would be remarkable indeed if none of them had surface indications, or that, if any were exposed, they could go unnoticed throughout the 60-year period during which bauxite has been mined in the region.

The limits of the bauxite field are fairly well defined, and can be drawn as smooth lines without too much generalization (fig. 1). As has long been recognized, the field continues westward to include the Rock Run district in Alabama. In part the limits of the field coincide with the boundaries of the area underlain by the Knox group, as east and south of
Rome and at the eastern termination of the field. Where the limits lie within the outcrop area of the Knox group, there is, presumably, some geologic explanation for their existence. It is possible, for example, that the southeastern limit of the field marks the border of a broad ancient valley bottom on which kaolin from the Piedmont was transported and deposited. But until we have a more complete knowledge of ancient physiography and drainage in the region, the boundaries of the field must remain empirical, and one can only say that at present the chances of new discovery beyond the limits seem to be much less than inside them.

\section{DESCRIPTIONS OF DEPOSITS}

About 180 bauxite deposits were examined by the writers, and each is briefly described below. Watson (1904, pp. 60-118) describes about 85 deposits within the area covered here, and all but a few of these were located; failure to find these few may be due to obliteration of the openings, as in cultivated areas, or to inaccurate or incomplete locations given by Watson. Deposits not described by Watson were found through inquiry among local residents and bauxite miners, and a few were encountered in the course of geologic mapping. The deposits described below are believed to include all the major mines and probably well over 90 percent of the known minor occurrences in the region examined. A few prospects that expose only material of doubtful bauxitic character are shown on the map but are not described in the text.

At most deposits little can be seen at present. Test holes and pit walls have slumped, and water, leaves, and surficial debris conceal almost everything that was exposed by the original openings. The nature of the material derived from an opening is generally best determined by examining the dumps and piles adjacent to holes and pits.

Although the descriptions of deposits are based primarily on the writers' own observations, they are supplemented in places with data from other sources. Local residents and bauxite miners have been regarded as reliable sources for such information as the original depth of pits now filled with water. And a few observations of a more geologic nature, such as the character of a pipelike mass of lignite in the Booger Hollow mine, were reported by so many individuals that they may be regarded as accurate. The principal source of supplementary information is the report of Watson (1904), who visited the district when many of the mines were operating. Although an attempt has been made to include a summary of Watson's data in many of the descriptions that follow, his report should be consulted for more detailed information.

Most of the chemical analyses given here are based on figures published by Watson. A few others are in the files of the Georgia Geological Survey at Atlanta. Analyses of samples collected by the writers were performed in the chemical laboratory of the U. S. Geological Survey.

The deposits are described by districts, in numerical order of section, district, and lot to facilitate cross-reference with the maps (pls. 1-3; figs. 2,3). Lot lines and at least the larger deposits are readily visible on aerial photographs in most 
parts of the area, and the location of deposits with respect to lots is velieved to be generally accurate in both maps and text. In a few heavily wooded areas, particularly that which lies southeast of Adairsville, the location of the deposits in relation to roads, drainage, and geologic boundaries is accurate, but there may be errors in their relation to lot lines as shown on the map and described in the text.

Deposits that have names are listed alphabetically and located by lot number in a gazetteer that follows the descriptions. The list is not complete, as the name of a mine may change when there is a change of operator or owner, but most of the names used by Watson (1904) and a large number of new ones are included.

\section{$\underline{\text { Hermitage district }}$}

Section 3, district 5

Lot 7.--The Curtis (also known as Cherokee, Akin, or Merrimac) mine lies mostly in the NE $\frac{1}{4}$ lot 7 , along ravines both east and west of a saddle. There are five large pits and many test holes in a line 1,500 feet long. The three easternmost pits form a continuous opening, and the other two are separated by areas containing fire clay or residual clay. The largest pit, near the western end of the line of openings, was probably about 100 by $350 \mathrm{ft}$ in original dimensions and as much as $50 \mathrm{ft}$ deep. Most of the walls of this pit now show residual clay. The walls of the eastern pits contain a large amount of bauxitic clay with scattered pebbles and boulders of pisolitic bauxite; walls of fire clay bound the bauxite on the north at all places, but the south boundary is mostly concealed by slump. The arrangement of pits and the exposures in them suggest that the deposit is a vertical tabular body of fire clay and bauxite, wide in some places and narrow in others, with walls of cherty residual clay. At the eastern end of the largest pit, for example, the deposit is represented by a narrow vertical vein-like mass of fire clay between walls of residual clay. Bauxite seems to form the core of the body in the wide places, now marked by pits. A sample from the drying bin, analyzed in 1929 by the Geological Survey of Georgia, contained 49.80 percent $\mathrm{Al}_{2} \mathrm{O}_{3}, 1.40$ percent $\mathrm{Fe}_{2} \mathrm{O}_{3}, 2.25$ percent $\mathrm{TiO}_{2}$, and 24.65 percent $\mathrm{SiO}_{2}$, with 21.90 percent ignition loss. Altitude 900-930 ft.

A prospect in the center of the NW $\frac{1}{4}$ lot 7 lies on the westward projection of the line of pits described above. This prospect, a pit 30 by $40 \mathrm{ft}$ across and $10 \mathrm{ft}$ deep, surrounded by test holes, is near the base of the north wall of a broad, deep ravine. The walls of the pit show a little pebble bauxite with boulders of hard white pisolitic bauxite. Altitude $910 \mathrm{ft}$.

Lot 9. --The Akin (Chisolm) mine lies in the NW $\frac{1}{4}$

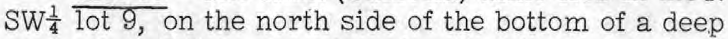
ravine and $700 \mathrm{ft}$ east of the head of the ravine. The pit is 100 by $120 \mathrm{ft}$ across and probably at least $30 \mathrm{ft}$ deep. The west wall contains a little white fire clay. Adjacent test holes are all in cherty clay. Scattered around the opening and on the dump are abundant bauxite pebbles and a few small boulders of hard white pisolitic bauxite. Most of the pebbles are massive, and lack typical concentric layers. Altitude $920 \mathrm{ft}$.
Bauxite was encountered in two test holes $70 \mathrm{ft}$ apart in the SW $\frac{1}{4} \mathrm{NE} \frac{1}{4}$ lot 9 , near the bottom of the same ravine. The debris scattered around these two holes includes a little white pisolitic bauxite. Other test holes nearby encountered only cherty material, but do not satisfactorily define the possible extent of the bauxite. Altitude $865 \mathrm{ft}$.

Between this last prospect and the Akin mine are several test holes, three of which show fire clay.

Lot 30.--The Gilreath prospect lies in the northwest corner of lot 30 , just north of the bottom of a broad ravine. About 25 test holes were put down here under the direction of the Georgia Geological Survey on the eastward projection of the Curtis mine (lot 7, same district). These holes block out an area of about 60 by $250 \mathrm{ft}$ that is underlain by ferruginous bauxitic clay. Altitude $885 \mathrm{ft}$.

Section 3, district 15

Lot 14. --There are a small shallow pit, about 80 by $25 \mathrm{ft}$ in area, and several barren test holes in the NE $\frac{1}{4} \mathrm{SE}_{\frac{1}{4}}$ lot 14 , on the south side of the bottom of a deep ravine. The walls of the pit are fire clay. Pieces of bauxite lying around the opening are pink or white, and include vesicular, pisolitic, and pebble varieties. Altitude $820 \mathrm{ft}$.

\section{Lot 23. --The McGuire prospects lie in the} western half of lot 23. The more westerly prospect, in a flat area at the head of a deep ravine, is a circular area about $80 \mathrm{ft}$ across with many test holes, all of which show bauxite. The material is a moderately hard pink bauxite with red pisolites that occurs both in massive form and as boulders in clay. Elevation $990 \mathrm{ft}$.

The more easterly prospect, on the rorth slope of the same ravine $400 \mathrm{ft}$ farther east, is an area about $200 \mathrm{ft}$ across that contains many test holes, mostly very shallow. Three holes within an area $50 \mathrm{ft}$ across reveal pebbles and boulders of hard red, very ferruginous bauxite in red clay. Altitude $975 \mathrm{ft}$.

Lot 31.--The Pinson mine is in the westernmost quarter of lot 31 (see footnote under lot 23), on the bottom and south wall of the head of a narrow ravine. There is one pit about $50 \mathrm{ft}$ in diameter and $20 \mathrm{ft}$ deep, surrounded by numerous test holes. An area about $100 \mathrm{ft}$ in diameter is underlain by bauxite and clay. The bauxite is pisolitic, soft, and white to pink in color. It occurs in massive form and as pebbles and boulders in bauxitic clay. Irregular layers and masses of fire clay may make up 50 percent of the total material present, and small veins of halloysite are common. Altitude $985 \mathrm{ft}$.

Lot 106. --The Davis No. 2 mine is in the SE $\frac{1}{4} \mathrm{NE} \frac{1}{4} \mathrm{NW} \frac{1}{4}$ lot 106 , at the bottom of a broad flat depression. A small pit and several test holes reveal bauxitic clay with pisolites and boulders of white pisolitic bauxite,

\footnotetext{
an addition to the regular series of lots in district 15, numbered $1-225$, there is an extra series of narrow rectangular lots, numbered 1-31, that lie along the eastern and southern boundaries of the district. The bauxite occurrences in the lots 23 and 31 described here belong to the extra series, and the occurrences in lots 14 and 106 to the regular series.
} 
according to Watson (1904, p. 76). This deposit was not visited by the writers. Altitude $910 \mathrm{ft}$.

Section 3, district 16

Lot 1. --There is a single test hole, 30 or $40 \mathrm{ft}$ deep, in the $S \frac{1}{2} \mathrm{NE} \frac{1}{4} \mathrm{NW} \frac{1}{4}$ lot 1 , at the base of the north slope of a small ravine. The bauxite lying around this hole is similar to that at the Pinson mine (lot 31, district 15). This is probably the Ridge Valley no. 2 prospect of Watson (1904, p. 67). Altitude $930 \mathrm{ft}$.

Slightly bauxitic pink clay is exposed in one small test hole in the middle of the $S W \frac{1}{4}$ lot 1 . Adjacent pits were all in ferruginous gravel. Altitude $945 \mathrm{ftc}$.

Lot 6. --The Davis no. 1 prospect is in the middle of the $\overline{S \frac{1}{2} S E \frac{1}{4}}$ lot 6 , in the bottom of a small ravine draining northwest. A pit, 30 by $10 \mathrm{ft}$ across and $8 \mathrm{ft}$ deep, exposes red clay with ferruginous bauxite boulders, and a little buff-colored bauxite with red pisolites. Altitude $980 \mathrm{ft}$.

A well dug in the middle of the east edge of the SE $\frac{1}{4}$ lot 6 encountered bauxite, according to several local residents.

Lot 8. --A 50-ft trench and one test hole have been dug in the NE $\frac{1}{4} \mathrm{SE}^{\frac{1}{4}}$ lot 8 , on the bottom and north slope of a broad shallow valley. The east end of the trench exposes clay with boulders and pebbles of hard white oolitic bauxite. Altitude $995 \mathrm{ft}$.

Lot 9.--Bauxite was mined from a small pit in the NW $\frac{1}{4} \mathrm{SW}^{\frac{1}{4}}$ lot 9 , in a broad saddle at the west end of a deep valley. The pit was probably about $30 \mathrm{ft}$ across and $30 \mathrm{ft}$ deep before it slumped. The walls now expose fire clay and residual clay. The material on the dump is soft pebble bauxite with some white oolitic bauxite. Altitude 1, $015 \mathrm{ft}$.

Lots 10 and 21.--The Terry-Shaw mine lies on both sides of the northern border of the NW $\frac{1}{4} \mathrm{NE} \frac{1}{4}$. lot 21 , on the crest of a high ridge. The pit covers an area about $200 \mathrm{ft}$ on a side and averages $20 \mathrm{ft}$ in depth; its walls and floor contain pink and red clay with scattered pebbles and boulders of hard pink and white pisolitic bauxite. The clay was washed from the pisolitic material to make a commercial product. Thirteen samples contained an average of 56.2 percent $\mathrm{A}_{2} \mathrm{O}_{3}, 3.07$ percent $\mathrm{Fe}_{2} \mathrm{O}_{3}, 2.98$ percent $\mathrm{TiO}_{2}$, and 7.82 percent $\mathrm{SiO}_{2}$ (Watson, 1904, p. 78). There is a large horse of cherty clay in the center of the pit, but the bottom of the deposit does not seem to have been reached. Altitude 1, $075 \mathrm{ft}$.

Lot 22. --The Sheets mine is in the NW $\frac{1}{4} \mathrm{SE} \frac{1}{4}$ lot 22 , at a fork in a deep ravine. It is a circular pit, about $70 \mathrm{ft}$ across and at least $25 \mathrm{ft}$ deep (Veatch, 1909, p. 274), now largely filled by gully wash. The walls are mostly residual clay except for some bauxite on the northeast side. The bauxite is soft and white, some pisolitic and some amorphous. Altitude $920 \mathrm{ft}$.

There is a long line of pits just north of the south boundary of lot 22 in the eastern two-thirds of the lot. These pits lie in a narrow zone 50-100 ft wide and 1, $200 \mathrm{ft}$ long, along the bottom and lower slopes of a ravine. The pits at the western end contain. hard red ferruginous pisolitic bauxite, and the others show banded red, pink, and white amorphous bauxitic clay and fire clay. Altitude 900-950 ft.

Lot 29. --The Hatter prospect lies in the NE $\frac{1}{4} \mathrm{NW} \frac{1}{4}$ lot 29 , on the north boundary of the lot, on the north side of a broad flat valley bottom. Watson (1904, p. 75) says, "Three shafts have been sunk to a depth of $30 \mathrm{ft}$ within a radius of $100 \mathrm{ft}$ of each other. The shafts penetrated ore for their entire depths. Both soft pebble and hard oolitic types of ore, usually red in color, occur mixed together." Hand-auger holes put down by the Bureau of Mines (Lewiecki, 1949) indicate a body of bauxite about 100 by 50-75 ft in area, and at least 50-60 ft deep.

The following table summarizes the detailed analytical data in the reference cited:

\begin{tabular}{l|c|c|c}
\hline & 1 & 2 & 3 \\
\hline $\mathrm{A}_{2} \mathrm{O}_{3----}$ & 41.36 & 47.79 & 53.1 \\
$\mathrm{SiO}_{2} \ldots--$ & 23.42 & 14.25 & 4.5 \\
$\mathrm{Fe}_{2} \mathrm{O}_{3-----}$ & 12.95 & 9.93 & 10.6 \\
$\mathrm{TiO}_{2-----}$ & 2.32 & 2.51 & 2.8 \\
Ignition loss-- & 19.48 & 25.02 & 28.9 \\
\hline
\end{tabular}

1. Average of 60 analyses of samples from holes $3,5,6,7,8,9,12$.

2. Average of 15 analyses of samples from hole 6, interval 2-47 ft. (The auger encountered the highest grade material at this hole).

3. Analysis of sample from 38-41 ft, hole 6 (richest sample).

The altitude of this deposit is $850 \mathrm{ft}$.

In the western part of the NW $\frac{1}{4} \mathrm{NW} \frac{1}{4}$ lot 29 , on the southwest side of a broad gentle depression, are three small shallow test holes. One shows pink bauxite with ferruginous vesicles and some halloysite. Altitude $895 \mathrm{ft}$.

Lot 30. --There are four test holes in the $\mathrm{NE} \frac{1}{4} \mathrm{NW}^{\frac{1}{4}} \mathrm{NW} \frac{1}{4}$ lot 30 , in a saddle on an east-west ridge. Two holes show hard red ferruginous bauxite, a third exposes amorphous, slightly bauxitic pink clay, and the last is slumped. Altitude $980 \mathrm{ft}$.

Lot 31. --See lot 60, district 16.

Lot 36. --The Morrow prospect is in the NW $\frac{1}{4} \mathrm{SW} \frac{1}{4}$ lot 36 ; it lies near the western base of a high ridge, on the north side of a ravine that cuts through the ridge. The prospect consists of a pit, 30 by $15 \mathrm{ft}$ in area and $8 \mathrm{ft}$ deep, and two test holes. White pebble and pisolitic bauxite is scattered around the pit and around one test hole $25 \mathrm{ft}$ away. Altitude $940 \mathrm{ft}$.

Lot 37. --A prospect in the NE $\frac{1}{4}$ SW $\frac{1}{4}$ lot 37 lies in a saddle, just east of the crest of a ridge. A pit, 30 by $15 \mathrm{ft}$ in area and probably $20 \mathrm{ft}$ deep before slumping, shows pebbles and boulders of white pisolitic bauxite in a matrix of red clay. In test holes to the east and west residual clay was encountered. This deposit, at an altitude of $1,110 \mathrm{ft}$, is the highest in the region. 
Lot 54. -- The Mary mine, in the SW $\frac{1}{4} \mathrm{SE} \frac{1}{4}$ lot 54, is on the steeply sloping eastern end of a ridge. A pit, 100 by $50 \mathrm{ft}$ across and about $15 \mathrm{ft}$ deep, exposes boulders of bauxite in pebbly bauxite clay, firm white pebbly bauxite, and some reddish pisolitic bauxite. The walls also contain abundant fire clay and some cherty residual clay. The ore body is very irregular, as indicated by the pit and adjacent test holes; it may extend south of the explored area. A layering of the clay and bauxite is apparent locally in the walls, and the layers dip gently southeast, more or less parallel with the slope of the surface; the deposit may be a thin blanket. Twelve samples of the ore mined contained an average of 58.98 percent $\mathrm{A}_{2} \mathrm{O}_{3}, 2.40$ percent $\mathrm{Fe}_{2} \mathrm{O}_{3}, 3.48$ percent $\mathrm{TiO}_{2}$, and 4.13 percent $\mathrm{SiO}_{2}$ (Watson, 1904, p. 81). Altitude 1, $020 \mathrm{ft}$.

At a fork in the ravine $400 \mathrm{ft}$ east of the Mary mine, in the SE $\frac{1}{4} \mathrm{SE}^{\frac{1}{4}}$ lot 54 , three test holes within an area $75 \mathrm{ft}$ across showed a little red and pink pisolitic bauxite with abundant ferruginous clay. Pits farther east disclosed cherty residual clay. Altitude $965 \mathrm{ft}$.

On the south slope of the ridge, $300 \mathrm{ft}$ west of the Mary mine, one test hole exposes some pink pisolitic bauxite and bauxite clay, but adjacent holes are all in residual clay. Altitude 1,040 ft.

Lot 58. --There are several test holes near the top of the north side of a small ravine in the middle of the NW $\frac{1}{4} S W \frac{1}{4}$ lot 58 . Two expose some ferruginous clay.

Lot 60.--The nature, location, topographic position, and altitude of the openings in lot 60 are shown in figure 3 . The Hardee mine consists of two contiguous funnel-shaped pits about $30 \mathrm{ft}$ deep. The walls are mostly pink and white fire clay with minor cherty clay. The bauxite on the dump is white, in part pebbly and in part pisolitic.

The North Hardee mine is a pit, possibly $30 \mathrm{ft}$ deep originally. The slumped walls contain a little fire clay, but mostly cherty residual clay. Bauxite scattered around the pit is light-colored to red, and either pisolitic or pebbly.

For $500 \mathrm{ft}$ northwest (extending into lot 31) and $700 \mathrm{ft}$ southeast of the North Hardee mine there are numerous test holes in a narrow zone. The holes have slumped, and it is difficult to tell which contained the bauxite that is strewn over the surface. Most of the holes seem to be in clay. The bauxite is mostly hard red highly ferruginous bauxite, but there is some of lighter color.

In the center of the southern half of lot 60 , there are several test holes (not shown in figure 3) in ferruginous clay. One pit contains some hard red material with an imperfect pisolitic structure.

Lot 65. --The Holt mine is in the SE $\frac{1}{4} \mathrm{NW}^{\frac{1}{4}}$ lot 65 , at the head of a broad shallow ravine on the west slope of a high ridge. It is a pit 70 by $25 \mathrm{ft}$ across and about $20 \mathrm{ft}$ deep, elongate east-west, with a shallow extension at the east end. The walls show - only mottled pink and white bauxitic clay and fire clay. The original ore was soft and pisolitic with scattered boulders of hard white pisolitic bauxite, and averaged about 55 percent $\mathrm{A}_{2} \mathrm{O}_{3}$ (Watson 1904, p. 82). Test holes put down north of the pit under the direction of the Georgia Geological Survey were mostly in fire clay. One hole $50 \mathrm{ft}$ north of the east end of the pit showed light-colored bauxitic clay with a few small boulders of bauxite. Altitude $940 \mathrm{ft}$.

Lot 75. --The Scott prospects are in the $S \frac{1}{2} \mathrm{NE} \frac{1}{4}$ lot 75 , in a broad valley. The more westerly prospect, on the south side of the valley bottom, is a large group of pits. One of these pits, $200 \mathrm{ft}$ east of the wagon road shown in plate 1 , contains boulders of very hard light-colored imperfectly pisolitic bauxite in light-colored bauxitic clay. Surrounding pits and test holes show white and red fire clay over an area 100 by $300 \mathrm{ft}$, elongate east-west, with residual clay to the north and south. Altitude $980 \mathrm{ft}$.

On the north side of the valley, $800 \mathrm{ft}$ farther east, there are 4 test pits in an east-west line about $150 \mathrm{ft}$ long. They contain bauxitic clay with some pebbles and boulders of light-colored pisolitic bauxite. Adjoining blank holes limit the width of the deposit to 50 or $60 \mathrm{ft}$. Altitude $980 \mathrm{ft}$.

Lot 97. --The Montague prospect lies at the base of a very steep slope on the western side of a watercourse in the SW $\frac{1}{4} \mathrm{SE} \frac{1}{4}$ lot 97 . It consists of eight test holes, one in clayey white bauxite with dark red pisolites, two others in amorphous reddish bauxite with dark red pisolites, two others in amorphous reddish bauxitic clay, and the remainder in residual clay. Altitude $840 \mathrm{ft}$.

Lot 98. --At the Green prospect, in the SE $\frac{1}{4} S E \frac{1}{4}$ lot 98 , one test hole south of the public road encountered a mass of hard white pisolitic siliceous bauxite, underlain by pebbly bauxite. The surrounding holes are all in residual clay. Altitude $815 \mathrm{ft}$.

The Green prospect described by Watson (1904, p. 87) as containing bauxitic clay is probably the small pit to the northwest across the public road.

Lot 102. --A prospect in the SE $\frac{1}{4} \mathrm{SW} \frac{1}{4}$ lot 102 , on the south side of a steep narrow ravine, may be the Spurlock prospect of Watson (1904, p. 87). One test hole here exposed amorphous bauxitic clay with a little white pisolitic bauxite, but surrounding holes are all in cherty residual clay. Altitude $920 \mathrm{ft}$.

Lot 107.--The Clemmons mine, in the $\mathrm{NE}^{\frac{1}{4}} \mathrm{NW} \frac{1}{4}$

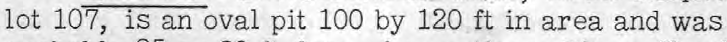
probably 25 or $30 \mathrm{ft}$ deep when active. The walls show only chert and residual clay. Bauxite lying around the opening and on the dump is white and coarsely vesicular. A composite sample analyzed by the Georgia Geological Survey contained 58.20 percent $\mathrm{A}_{2} \mathrm{O}_{3}, 1.45$ percent $\mathrm{Fe}_{2} \mathrm{O}_{3}, 4.05$ percent $\mathrm{TiO}_{2}$, 6.69 percent $\mathrm{SiO}_{2}$, and 29.32 percent $\mathrm{H}_{2} \mathrm{O}$. Test holes adjacent to the pit are all in cherty clay. Altitude $1,000 \mathrm{ft}$.

On the same gentle slope, $200 \mathrm{ft}$ east of the mine, a few pink to white, hard vesicular bauxite fragments are scattered around two test holes.

Lot 108. --The Warner (also known as Warring) mine is in the $\mathrm{NE} \frac{1}{4} \mathrm{NE} \frac{1}{4}$ lot 108, on the gently sloping north side of a broad valley. It is a pit about $100 \mathrm{ft}$ 
across, and was perhaps 25-35 ft deep originally. A little fire clay and soft bauxite with brown crumbly pisolites are exposed in the west wall, but the other walls are all of residual clay. Surrounding test holes, except one on the north side, are in residual clay. Bauxite on the dump is hard, white, and pisolitic. Altitude 1, $000 \mathrm{ft}$.

Test holes, all in cherty clay, have been dug every 150 to $200 \mathrm{ft}$ on a line eastward to the Clemmons mine in lot 107.

In the middle of the north boundary of the NW $\frac{1}{4}$ lot 108, in a saddle on the crest of Caswell Mountain, there are three deep test holes in an area $75 \mathrm{ft}$ across. A hole in the center of this area contains some hard bauxite, made up of white pebbles and pisolites in a pink and white, somewhat brecciated matrix. The other holes are all in cherty clay. Altitude 1,050 ft.

Lot 109.--In the SE $\frac{1}{4} \mathrm{NE} \frac{1}{4}$ lot 109, in a broad saddle on the crest of Caswell Mountain, there is a pit 40 by $20 \mathrm{ft}$ in extent and $12 \mathrm{ft}$ deep, surrounded by testholes. The walls of the pit show only mottled pink clay. Pebbles and boulders of hard pink and white bauxite are scattered around the pit and around the test holes within $50 \mathrm{ft}$ of the pit. Altitude 1,005 ft.

Lot 115. --A prospect in the center of the NW $\frac{1}{4} S_{W} \frac{1}{4}$ lot 115 lies on the lower valley slope just west of Barnsley Creek. It consists of two test holes, $80 \mathrm{ft}$ apart, that expose red clay with pebbles and boulders of hard red and brown pisolitic bauxite. There are other holes in the vicinity, all in cherty clay, but they do not delimit the deposit. Altitude $770 \mathrm{ft}$.

Lot 117. --The Julia mine, largest in the district,

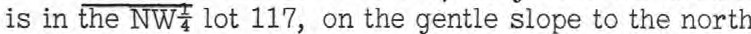
of a broad flat bottom. This mine, whose total production prior to 1942 is estimated to have been about 70,000 tons, consists of two circular pits about $300 \mathrm{ft}$ apart, each about $220 \mathrm{ft}$ across. The northwestern, or no. 1, pit was mined to a depth of $90 \mathrm{ft}$, and the bauxite is known to extend at least $40 \mathrm{ft}$ deeper. The bauxite was mostly coarse pebble ore with some boulders. No. 2 pit was mined to a depth of $60 \mathrm{ft}$, but there was 15-20 ft of slumped material covering the bottom when the pit was pumped out in 1942. Test shafts dug in the north part of the bottom at this time indicated reserves of over 20,000 tons. The ore in these shafts is soft, mottled pink and white bauxite, with abundant imperfectly formed pisolites, and with many pebbles and boulders of hard pink and white pisolitic bauxite. The average of 25 analyses of bauxite from the Julia mine (Watson, 1904, p. 86), probably from both pits, is 58.2 percent $\mathrm{A}_{1} \mathrm{O}_{3}$, 1.08 percent $\mathrm{Fe}_{2} \mathrm{O}_{3}, 4.09$ percent $\mathrm{TiO}_{2}$, and 6.41 percent Si02. Two samples from no. 2, pit analyzed more recently by the Georgia Geological Survey contained an average of about 55 percent $\mathrm{A}_{2} \mathrm{O}_{3}$ when recalculated to 30 percent moisture. Altitude $850 \mathrm{ft}$.

Between and slightly south of the two main pits is a small pit, now largely filled by dump.

In the SW $\frac{1}{4} \mathrm{NE} \frac{1}{4}$ lot $117,900 \mathrm{ft}$ southeast of the Julia mine, there was a small pit that is now filled in. The material on the dump is white pebble and pisolitic bauxite. Scattered test holes between this dump and the Julia mine seem too shallow to have penetrated the overburden. Altitude $860 \mathrm{ft}$.

Northeast of the Julia no. 2 pit, in the SW $\frac{1}{4} \mathrm{NW} \frac{1}{4} \mathrm{NE} \frac{1}{4}$ lot 117 , is a 15 -ft test hole in white bauxitic clay, and a long trench and many auger holes in cherty clay. Altitude $870 \mathrm{ft}$.

Lot 128. --The Conneseena (also known as the Felder or Knowles) mine is a long line of pits and test holes in the middle of the southern half of lot 128, along the bottom of a ravine. These openings fall within an area about $500 \mathrm{ft}$ long, measured nearly eastwest, and about $50 \mathrm{ft}$ wide. None of the pits seem to be more than $20 \mathrm{ft}$ deep, and the largest is only $50 \mathrm{ft}$ across. Most of the bauxite consists of light-colored pisolitic boulders and pebbles in a matrix of reddish clay and bauxitic clay. Locally the bauxite is coarse, white, and vesicular or pebbly. The westernmost openings contain much pink amorphous bauxitic clay. The few observed contacts between different kinds of bauxite and clay appear to strike parallel to the elongation of the deposit and to dip steeply, suggesting that the deposit as a whole may be a steeply-dipping vein-like body similar to that of the Curtis mine (district 5, lot 7), described above. Four samples of bauxite from this mine, analyzed by the Georgia Geological Survey, contained an average of 54.35 percent $\mathrm{Al}_{2} \mathrm{O}_{3}, 4.76$ percent $\mathrm{Fe}_{2} \mathrm{O}_{3}, 2.76$ percent $\mathrm{TiO}_{2}$, and 10.63 percent $\mathrm{SiO}_{2}$, with 26.05 percent ignition loss. Altitude 780-800 ft.

Well-rounded pebbles of coarse-grained quartzite, found in the pink and white residual clay adjacent to the bauxite in the westernmost pit,indicate that drainage from the Piedmont province once crossed this area. This fact may bear on the origin of the kaolin clays from which the bauxite is presumed to have formed (Bridge, 1950, p. 195).

On the south side of the bottom of the ravine, $400 \mathrm{ft}$ east of the Conneseena mine, several test holes expose a deposit of bauxite at least $120 \mathrm{ft}$ long and of unknown width. The exposed material is bauxitic clay with pebbles and boulders of hard white pisolitic bauxite. This prospect may be on a continuation of the Conneseena "vein", but test holes in the intervening $400 \mathrm{ft}$ are too few to establish or disprove the continuity. Altitude $740 \mathrm{ft}$.

Lot 142.--The McGuire mine lies on the south side of a hilltop, at the head of a ravine, in the $\mathrm{NE} \frac{1}{4} \mathrm{NE} \frac{1}{4}$ lot 142 . It is a shallow pit 60 by $40 \mathrm{ft}$ in area whose walls show only residual clay and a little fire clay. The ore was hard light-colored pisolitic bauxite in a matrix of bauxitic clay, from which the bauxite was concentrated by washing. Test holes east of the pit, some dug under direction of the Geological Survey of Georgia, show a little fire clay, but the area west of the pit was not prospected. Altitude $840 \mathrm{ft}$.

Lot 175.--In the NW $\frac{1}{4} \mathrm{SE} \frac{1}{4}$ lot 175 , on the west side of a flat-topped ridge, there is one test hole in soft bauxitic clay with scattered pisolites. Adjacent holes are all in residual clay. Altitude $800 \mathrm{ft}$.

Lot 176.--The Hawkins (also known as Shaw) mine lies in the NW $\frac{1}{4} \mathrm{SE}^{\frac{1}{4}}$ lot 176 , on the east side of the broad valley bottom of Barnsley Creek. It is a 
large oval pit, about 150 by $225 \mathrm{ft}$ across, and said to be 30-40 ft deep; it is now filled almost to its rim with water. The walls show only fire clay and residual clay, and there is not enough bauxite lying around on the surface to indicate the character of the ore. Altitude $695 \mathrm{ft}$.

Section 3, district 23

Lot 20.--A prospect on the west edge of the $\mathrm{SW} \frac{1}{4} \mathrm{NW} \frac{1}{4}$ lot 20 lies on the steep western slope of Armstrong Mountain, about $200 \mathrm{ft}$ from the crest. Two test holes and 25 auger holes outline an oval ore body about 100 by $150 \mathrm{ft}$ in area, with a maximum thickness of $32 \mathrm{ft}$. The bauxite is hard and white with red pisolites. Altitude 1, $060 \mathrm{ft}$.

In the middle of the $\mathrm{NW} \frac{1}{4}$ lot 20 , on the crest of the ridge, there are three small test holes, one of which shows some bauxitic clay.

In the middle of the north line of lot 20 , just west of the crest of the ridge, there are several test pits, one $20 \mathrm{ft}$ long. The largest shows bauxitic clay, and the others fire clay or chert.

Lot 21. --The Stockade mine is in the SW $\frac{1}{4} \mathrm{NW} \frac{1}{4}$ lot 21, on the lower slope south of a high ridge. The pit is about 150 by $60 \mathrm{ft}$ in area, elongate north-northwest, and is surrounded by many test holes. The ore consisted of boulders of hard buff pebbly bauxite in soft red pebbly bauxitic clay and fire clay. According to Watson $(1904$, p. 68), 60 tons of ore contained an average of 58.34 percent $\mathrm{Al}_{2} \mathrm{O}_{3}, 4.51$ percent $\mathrm{Fe}_{2} \mathrm{O}_{3}$, 3.40 percent $\mathrm{TiO}_{2}$, and 3.35 percent $\mathrm{SiO}_{2}$, with 30.40 percent ignition loss. Altitude $985 \mathrm{ft}$,

An opening in the center of the $\mathrm{W} \frac{1}{2}$ lot 21 , on the south side of a broad valley bottom, may be the Flowery Branch deposit of Watson (1904, p. 69). A small pit $30 \mathrm{ft}$ across exposes pink and white clay with a little soft, pink, vesicular bauxite. Altitude $940 \mathrm{ft}$.

Lot 22. --The Armstrong mine, in the center of lot 22, lies on the steep north wall of a broad ravine. A. little fire clay is exposed in the badly slumped walls of a pit about $80 \mathrm{ft}$ across. The bauxite on the dump is red and white, and pisolitic. The size of the dump suggests a high proportion of waste to ore. Altitude $990 \mathrm{ft}$.

The Grier mine is in the NW $\frac{1}{4} \mathrm{NE} \frac{1}{4}$ lot 22 , at a fork in the bottom of a broad ravine. It is a circular pit $20 \mathrm{ft}$ across, with several adjacent test holes. The ore was soft white pebble bauxite with minor hard pisolitic bauxite (Watson, 1904, p. 69). Twenty tons contained an average of 59.2 percent $\mathrm{A}_{2}{ }_{2} \mathrm{O}_{3}, 3.16$ percent $\mathrm{Fe}_{2} \mathrm{O}_{3}, 3.60$ percent $\mathrm{TiO}_{2}$, and 3.30 percent SiO2. Altitude $965 \mathrm{ft}$.

A small test hole in a roadcut in the $\mathrm{SE} \frac{1}{4} \mathrm{SE} \frac{1}{4}$ lot 22 apparently worked out a small pocket of hard red very pisolitic bauxite.

Lot 60. --Several small test holes in the southeast corner of lot 60 (fig. 3) are mostly in chert with a little fire clay, but several pieces of hard white pisolitic bauxite are strewn on the surface around two of them. This is probably part of Watson's (1904, p. 65) Ridge Valley no. 1 prospect.
Lot 61.--Lot 61 contains most of the Holland group of pits, whose size, location, topographic position, and altitude are shown in figure 3. The pits are mostly full of water and badly slumped.

The walls of the Holland mine show mostly residual clay, with a little fire clay. Watson (1904, p. 63) describes the ore as hard light-colored bauxite with dark crumbly ferruginous pisolites. A shipment of 106 carloads contained an average of 52.93 percent $\mathrm{Al}_{2} \mathrm{O}_{3}, 9.23$ percent $\mathrm{Fe}_{2} \mathrm{O}_{3}, 3.49$ percent $\mathrm{TiO}_{2}$, and 4.55 percent $\mathrm{SiO}_{2}$, with 29.80 percent ignition loss. The first shipments of bauxite in the United States came from this opening.

The Holland Hill mine was $75 \mathrm{ft}$ deep (Veatch, 1909 , p. 266). Only cherty red clay can be seen in its slumped walls. Fragments of fine white pisolitic bauxite are strewn around the opening. This must be the more westerly of two pits described by Watson (1904, p. 63) as the Church bank.

The walls of the Holland Spring mine show cherty residual clay and a little fire clay. Watson (1904, p. 61) describes the ore from this mine as "a soft bauxitic clay through which are scattered small varicolored concretions." Some of the ore was hard, buffcolored, and oolitic. The ore body was cut by veins and horses of clay several feet in width, and small lenses of halloysite were abundant in the bauxitic clay.

The Discovery pit shows red clay and a little coarse pisolitic bauxite in its slumped walls. The first material identified as bauxite in the United States was taken from this pit, according to Mr. W. T. Watters.

The Holland House mine was probably about $40 \mathrm{ft}$ deep when operated. The walls now show mostly fire clay and cherty clay, but a few patches of soft white bauxite and hard pisolitic bauxite remain. The dump contains some hard pisolitic boulders. A hundred tons of ore contained an average of 51.65 percent $\mathrm{A}_{2} \mathrm{O}_{3}, 1.29$ percent $\mathrm{Fe}_{2} \mathrm{O}_{3}, 3.49$ percent $\mathrm{TiO}_{2}$, and 10.62 percent $\mathrm{SiO}_{2}$, with 32.45 percent ignition loss (Watson, 1904, p. 62).

The Church mine, largest of the Holland pits, was at least $75 \mathrm{ft}$ deep when operated (Veatch, 1909, p. 266). Only cherty clay is now exposed in the walls. Watson $(1904$, p. 63) describes the ore as soft pebbly bauxite with subordinate hard pisolitic bauxite. Three hundred tons contained an average of 55.30 percent $\mathrm{Al}_{2} \mathrm{O}_{3}, 1.02$ percent $\mathrm{Fe}_{2} \mathrm{O}_{3}, 4.04$ percent $\mathrm{TiO}_{2}$, and 8. 04 percent $\mathrm{SiO}_{2}$.

The walls of the Southwest Lenning mine show mostly white fire clay with a little pisolitic and pebbly white bauxite. Test holes on the south side are in residual clay.

The Northeast Lenning mine shows only cherty clay and a little fire clay in its walls. The ore was white bauxite with brown pisolites. Test holes to the east and west show no bauxite.

In the northeast corner of lot 61 , three test holes about $10 \mathrm{ft}$ deep in a north-south line show hard, red, coarsely pisolitic bauxite. Surrounding holes show none. This is probably part of Watson's $(1904$, p. 65) Ridge Valley no. 1 prospect. 
Lot 62. --The New Holland mine (fig. 3) contained hard white pebble and oolitic bauxite. A large amount of bauxite was left in the north wall and bottom.

A small pit $550 \mathrm{ft}$ north of the New Holland mine contains white bauxitic clay. A small opening just west of the Holland Spring mine (fig. 3) shows only slumped surface debris.

In the $N E \frac{1}{4} N W \frac{1}{4}$ lot 62 , at the head of the ravine that runs past the southwest side of the New Holland mine, there are numerous test holes and auger holes on both sides of the road. One hole encountered boulders of very high grade bauxite, but nothing was found in the others.

There is an irregular line of pits from top to bottom of the southeast slope of the hill in the $S \frac{1}{2} S E \frac{1}{4}$ lot 62 . None shows bauxite, but some bauxite float was found here.

Lot 98.--There is a deep test hole and a 40-ft trench in the middle of the steep south wall of a deep ravine, in the NW $\frac{1}{4} \mathrm{NE} \frac{1}{4}$ lot 98 . Fragments of hard light-colored bauxite with red pisolites are scattered about these openings. Test holes down the slope show no bauxite.

Lot 102. -- The more northerly of the two Otts mines lies in the NW $\frac{1}{4}$ SE $\frac{1}{4}$ lot 102 , near the head of a shallow ravine, on the south side of a broad ridge. The pit is about 100 by $50 \mathrm{ft}$ in area and its slumped walls are largely residual clay. The material on the dump is hard white pisolitic bauxite. Altitude $830 \mathrm{ft}$.

The more southerly Otts mine lies on a gentle slope near the southern base of the same ridge, in the $\mathrm{SE} \frac{1}{4} \mathrm{SE} \frac{1}{4}$ lot 102 . It is a funnel-shaped pit about $50 \mathrm{ft}$ across. Most of the walls contain cherty clay and fire clay. The north wall exposes boulders of pink to white pisolitic bauxite in a clay matrix. Altitude: $795 \mathrm{ft}$.

There is a prospect high on the east wall of a ravine in the NW $\frac{1}{4} \mathrm{SW} \frac{1}{4}$ lot 102 . Three test holes within $30 \mathrm{ft}$ of one another penetrated pink pisolitic bauxite, and a fourth hole nearby contains fire clay. There are barren holes just to the north, but the deposit is unexplored to the south. Altitude $915 \mathrm{ft}$.

Lot 103.--A prospect in the NW $\frac{1}{4} \mathrm{NE} \frac{1}{4}$ lot 103 lies on the west side of the crest of a high ridge. Several test holes partly block out an area from 30$50 \mathrm{ft}$ across that contains hard red pisolitic bauxite. Cavities between some of the pisolites contain manganese oxide. Altitude $970 \mathrm{ft}$.

There is a small slumped opening just north of a saddle in the southeast corner of the NW $\frac{1}{4}$ lot 103. According to Watson (1904, p. 66), the original opening was 25 by $18 \mathrm{ft}$ in area and $35 \mathrm{ft}$ deep and contained light-colored pebble bauxite. He gives the following analysis of 40 tons of ore: 57.06 percent $\mathrm{Al}_{2} \mathrm{O}_{3}, 1.80$ percent $\mathrm{Fe}_{2} \mathrm{O}_{3}, 3.68$ percent $\mathrm{TiO}_{2}$, and 6.32 percent $\mathrm{SiO}_{2}$, with 30.54 percent ignition loss. The present walls expose fire clay and bauxitic clay on the south and east, cherty clay elsewhere. Altitude $910 \mathrm{ft}$.
A pit 100 by $30 \mathrm{ft}$ in area has been driven north into the south slope of a high ridge in the NW $\frac{1}{4} \mathrm{SW}^{\frac{1}{4}}$ lot 103. The east wall contains bauxitic clay, locally pisolitic, and some hard pisolitic bauxite. The other walls show mottled pink and white fire clay and cherty clay. Altitude $900 \mathrm{ft}$.

A hole $50 \mathrm{ft}$ northeast of this pit, and others $300 \mathrm{ft}$ southwest, penetrated hard red pisolitic bauxite; holes adjoining these are in residual clay but do not fully block cut what might be a large deposit.

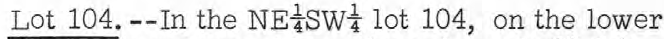
west slope of a narrow ridge, there is a pit $30 \mathrm{ft}$ across, its walls badly slumped. Around it are scattered fragments of brown pisolitic bauxite. Altitude $845 \mathrm{ft}$.

On the east slope of the same ridge, in the NW $\frac{1}{4} \mathrm{SE} \frac{1}{4}$ lot 104, there are several test holes, mostly in residual clay. A few fragments of ferruginous bauxite are. scattered around one hole, and another, $100 \mathrm{ft}$ away, shows a little fire clay. Altitude $870 \mathrm{ft}$.

Lot 105. --The Ward mine is in the SE $\frac{1}{4} \mathrm{SE} \frac{1}{4}$ lot 105, on the south slope of a low hill. A pit $60 \mathrm{ft}$ across and about $40 \mathrm{ft}$ deep exposes cherty clay in its walls. Bauxite on the dump is soft to hard, lightcolored bauxite; most of the pisolites are white, but some are red. Altitude $895 \mathrm{ft}$.

Lot 134. --The Wright (Hight) mine, in the $\mathrm{SW} \frac{1}{4} S \mathrm{~W}^{\frac{1}{4}}$ lot 134, lies on the gentle east slope of a hilltop. It consists of two contiguous oval pits, 25-35 ft deep, covering an aggregate area of 300 by $100 \mathrm{ft}$. The walls though mostly slumped, show some pink and white clay and a little bauxitic clay with pebbles and boulders of bauxite. The ore was soft light-colored pisolitic bauxite with hard white pisolitic pebbles and boulders. Altitude $940 \mathrm{ft}$.

Lot 136. --The Watters prospect is in the NW $\frac{1}{4} \mathrm{NW} \frac{1}{4}$

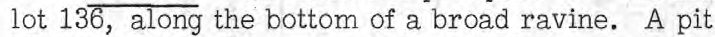
$20 \mathrm{ft}$ across and a number of test holes, some of which were put down under the direction of the Georgia Geological Survey, block out a circular deposit about $150 \mathrm{ft}$ across. The bauxite is white and coarsely vesicular, with abundant clay. Altitude $820 \mathrm{ft}$.

Lot 137.--The Kerce prospect, in the SW $\frac{1}{4} \mathrm{NW} \frac{1}{4}$

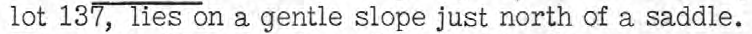
There are 35 test holes, five of which block out a bauxite deposit about 120 by $30 \mathrm{ft}$ in extent, elongate west-northwest. Members of the Georgia Geological Survey directed some of the exploration. The material exposed is hard red to light-colored pisolitic bauxite with abundant clay. Altitude $860 \mathrm{ft}$.

In the southwest corner of the SW $\frac{1}{4} \mathrm{NE} \frac{1}{4}$ lot 137 , on the north side of a broad flat depression, there were at least 3 old test holes that are now filled. Fragments of hard white pisolitic bauxite are scattered on the surface.

There was another old test hole, also filled now, $300 \mathrm{ft} \mathrm{N.} 60^{\circ} \mathrm{W}$. of the above. A few fragments of very coarse vesicular bauxite lie on the surface. 
In the $\mathrm{W} \frac{1}{2} \mathrm{SE} \frac{1}{4} \mathrm{NE} \frac{1}{4}$ lot 137 , on the crest of a low ridge, are two holes covered with brush and rubbish. One exposes reddish fire clay, and hard gray pisolitic bauxite is scattered around the other. On a gentle slope south of a watercourse, $500 \mathrm{ft}$ east-northeast of these holes, are several small test holes, some in very ferruginous hard pisolitic bauxite.

The prospects in the eastern two-thirds of lot 137 were described by Watson $(1904, p$. 67) as the Braden bank.

Lot 138. --The Maddox mine lies in a broad flat valley $\overline{\text { bottom, }}$ in the NW $\frac{1}{4} \mathrm{NE} \frac{1}{4}$ lot 138 . There are two contiguous circular pits, with an aggregate area of about 275 by $130 \mathrm{ft}$, filled to their rims with water. According to Watson (1904, p. 71), the ore consisted of hard and soft pisolitic bauxite, generally white, with some highly ferruginous red masses. He gives 3 analyses, which average 62.35 percent $\mathrm{A}_{2} \mathrm{O}_{3}$, 2.51 percent $\mathrm{Fe}_{2} \mathrm{O}_{3}$, and 4.32 percent $\mathrm{SiO}_{2}$. Altitude $805 \mathrm{ft}$.

Lot 147. --The Watters (Perry) mine lies on the gentle south slope of a hilltop, in the NW $\frac{1}{4} \mathrm{NW}^{\frac{1}{4}}$ lot 147 , crossing slightly into lot 148. It consists of two large contiguous pits, separated by a knife-edge chert ridge, which together have produced about 60,000 tons of bauxite. The larger, northwestern pit is 350 by $200 \mathrm{ft}$ in area and at least $50 \mathrm{ft}$ deep. It shows only cherty clay in its walls, except for a little bauxitic clay at the southwestern end. According to Watson (1904, p. 73) the ore was soft light-colored pisolitic bauxite with hard white pisolitic pebbles and boulders. Fourteen samples contained an average of 56.6 percent $\mathrm{A}_{2} \mathrm{O}_{3}, 1.1$ percent $\mathrm{Fe}_{2} \mathrm{O}_{3}$, and 7.2 percent $\mathrm{SiO}_{2}$. The southeastern pit is $250 \mathrm{ft}$ long, $175 \mathrm{ft}$ wide, and $30 \mathrm{ft}$ deep. It has cherty clay, and abundant bauxitic clay with white pebbles in its walls. Watson (1904, p. 73) describes the ore as soft ferruginous pebbly bauxite with some boulders. Eleven samples contained an average of 49.7 percent $\mathrm{A}_{2} \mathrm{O}_{3}, 1.77$ percent $\mathrm{Fe}_{2} \mathrm{O}_{3}$, and 10.6 percent $\mathrm{SiO}_{2}$. Altitude $935 \mathrm{ft}$.

Lot 148. --The Burney mine is at the north end of a deep ravine in the $\mathrm{NE}_{\frac{1}{4}} \mathrm{NE}^{\frac{1}{4}}$ lot 148 . The pit is about $100 \mathrm{ft}$ long, $80 \mathrm{ft}$ wide, and $20 \mathrm{ft}$ deep. Only cherty clay is now exposed in the walls. Boulders of hard white pisolitic bauxite are scattered around the opening, and Watson (1904, p. 75) describes openings dug in white bauxitic clay. Numerous test holes around the mine and for several hundred feet south exposed only cherty clay. Altitude $920 \mathrm{ft}$.

\section{Bobo district}

Section 3, district 22

Lot 10.--The Duke prospect is exposed in cross-section in the south bank of a deep gully in the middle of the north boundary of lot 10. The deposit is a small basin-shaped pocket of bauxitic clay $15 \mathrm{ft}$ across bounded on the east, west, and below by ferruginous sandy clay. There are three boulders of hard white pisolitic bauxite in the upper part of the mass of bauxitic clay. The north bank of the gully shows no bauxite, nor does a test hole $50 \mathrm{ft}$ south of the gully.
Lot 12. --There is a small prospect on the easi side of the bottom of a deep ravine, in the center of the west edge of the SW $\frac{1}{4} \mathrm{NE} \frac{1}{4}$ lot 12 . One test hole in clay has red pisolitic bauxite and ferruginous pellets scattered around the opening. Surrounding holes within $50 \mathrm{ft}$ are all in residual clay. Altitude $855 \mathrm{ft}$.

Lot 13.--The two Minter mines in lot 13 are here designated the Northwest and Southeast, respectively. The Northwest Minter mine, in the NE $\frac{1}{4} \mathrm{NW} \frac{1}{4}$ lot 13 , is in the bottom of a deep ravine whose head is just south of the mine. It is a nearly circular pit about $.75 \mathrm{ft}$ across and was $40 \mathrm{ft}$ deep when visited by Watson (1904, p. 106). The ore, as described by Watson, consisted of boulders of hard white pisolitic bauxite in a soft, crumbly matrix of bauxitic clay. Two samples of the bauxite contained an average of 61.61 percent $\mathrm{A}_{2} \mathrm{O}_{3}, 1.12$ percent $\mathrm{Fe}_{2} \mathrm{O}_{3}, 6.95$ percent $\mathrm{SiO}_{2}$, and 7.95 percent insoluble matter. Numerous test holes surrounding the pit are all in cherty residual clay. Altitude $875 \mathrm{ft}$.

The Southeast Minter mine, in the $\mathrm{NE} \frac{1}{4} \mathrm{SE} \frac{1}{4}$ lot 13 , is on the south slope of a hill well above the bottom of a broad ravine. It is a pit 80 by $120 \mathrm{ft}$ across and as much as $20 \mathrm{ft}$ deep. Material exposed in the walls by slumping is predominantly fire clay, but there is a little pink and white, soft, pisolitic and pebbly bauxite in the southeast side. A few fragments of hard white pisolitic bauxite are scattered around the opening. Test holes surrounding the pit are all in residual clay. Altitude $880 \mathrm{ft}$.

Lot 14. --Two test holes in the northeast corner of lot 14,part way up the steep southeastern side of a broad flat-floored valley, expose fire clay and a little soft white pisolitic bauxite. Altitude $875 \mathrm{ft}$.

The Branon prospect, in the northwest corner of lot 14, is on the lower slope north of a broad flatbottomed ravine. It consists of several deep test holes and a stripped area 20 by $30 \mathrm{ft}$ in extent. The area underlain by bauxite is at least 50 by $30 \mathrm{ft}$ and may be larger. A small pile next to the stripped area contains fragments of hard white pisolitic bauxite. Altitude $855 \mathrm{ft}$.

Lot 15. --The Drummond mine is in the SW $\frac{1}{4} \mathrm{SE} \frac{1}{4}$ lot 15 , on the southern slope of a hill above the head of a broad ravine. Only fire clay and cherty clay are exposed in the walls of a pit $120 \mathrm{ft}$ long, $50 \mathrm{ft}$ wide, and 30 or $35 \mathrm{ft}$ deep, and in adjacent test holes. The ore consisted of pebbles and boulders of hard white pisolitic bauxite in a softer matrix. Altitude $970 \mathrm{ft}$.

The Bush Washington prospect, in the SE $\frac{1}{4} \mathrm{SW} \frac{1}{4}$ lot 15 , lies in a saddle between two hills. Test holes block out an area of about 50 by $100 \mathrm{ft}$ underlain by white bauxitic clay containing a small proportion of white bauxite pebbles. Altitude $900 \mathrm{ft}$.

Lot 20. --The Drummond prospect, in the $\mathrm{SW} \frac{1}{4} \mathrm{NW} \frac{1}{4}$ lot 20 , lies on the gentle slope at the eastern head of a broad valley. It is a pit about 25 by $30 \mathrm{ft}$ in area and $12 \mathrm{ft}$ deep. The walls are badly slumped, but the western face exposes a nearly vertical contact between a mass of soft pink clayey bauxite with imperfect pisolites and stringers of halloysite, and some gritty white clay. Adjacent test holes show no bauxite. 
Lot 21.--In the ditch and on the bank west of the Central of Georgia Railway tracks, $250 \mathrm{ft}$ south of Relay station (NW $\frac{1}{4} \mathrm{SE} \frac{1}{4}$ lot 21, ) there are many pebbles and fragments of hard white pisolitic bauxite. They may have fallen from a loaded car left on the siding, but local residents state that no bauxite was ever loaded here. The ditch exposes white clay.

Lot 23. --Two large mines have been opened on Ware Mountain in lot 23. The North Ware Mountain mine is in the SE $\frac{1}{4} \mathrm{NW} \frac{1}{4}$ lot 23 , on the east side of the broad crest of the mountain. In the northeast corner of the pit, which is about 150 by $100 \mathrm{ft}$ in area and at least $30 \mathrm{ft}$ deep, there is some brown and white bauxitic clay containing pebbles and boulders of hard white pisolitic bauxite. The remaining walls show fire clay and cherty residual clay; the fire clay is everywhere on the pit side of the residual clay, and the contacts between fire clay and residual clay dip inward under the ore. Altitude $950 \mathrm{ft}$.

The South Ware Mountain mine, in the NE $\frac{1}{4} \mathrm{SW} \frac{1}{4}$ lot 23 , is at a fork on the south side of a broad ravine cutting the east slope of the mountain. The pit is 130 by $60 \mathrm{ft}$ in area. In the west wall, there is some soft white bauxite, or bauxitic clay, with pebbles and boulders of hard white pisolitic bauxite. The remaining walls expose fire clay and a little cherty clay. Altitude $935 \mathrm{ft}$.

Lot 25.--In the middle of the north edge of the $\mathrm{SE} \frac{1}{4} \mathrm{lot} 25$, on the upper slope south of a deep ravine, is a pit 7 by $25 \mathrm{ft}$ in area and $15 \mathrm{ft}$ deep. The walls and bottom expose red and white fire clay, locally cherty. Boulders of hard, pink to white, imperfectly pisolitic bauxite are stacked nearby. A sample of this bauxite collected by the writers contained 49 per-. cent $\mathrm{A}_{2} \mathrm{O}_{3}, 3.72$ percent $\mathrm{Fe}_{2} \mathrm{O}_{3}, 3.50$ percent $\mathrm{TiO}_{2}$, and 13.22 percent $\mathrm{SiO}_{2}$.

Lot 48. --The Jeff Washington mine, in the SE $\frac{1}{4} \mathrm{NW}^{\frac{1}{4}}$ lot 48 , lies on the south and southwest slopes of a low hill. The two pits are $75 \mathrm{ft}$ apart on an east-west line. The eastern pit is $30 \mathrm{by} 40 \mathrm{ft}$ in area and $20 \mathrm{ft}$ deep. The walls show only fire clay, but some pebbles and boulders of hard white pisolitic bauxite are scattered around two test holes put down in the bottom under the direction of the Georgia Geological Survey. The western pit is 30 by $25 \mathrm{ft}$ in area, and $8 \mathrm{ft}$ deep. The north wall and bottom expose a little pink and white amorphous bauxite, but test holes surrounding the pit are all in cherty clay. Altitude $850 \mathrm{ft}$.

Many test holes have been dug, some under the direction of the Georgia Geological Survey, in the $\mathrm{SW} \frac{1}{4} \mathrm{NE} \frac{1}{4}$ lot 48 , on the west slope of a low hill. These holes block out an area of about 120 by $30 \mathrm{ft}$ that is underlain by fire clay, and a few pebbles and fragments of white pisolitic bauxite are scattered around on the surface. Altitude $850 \mathrm{ft}$.

Two samples of bauxite from lot 48 , collected by the Georgia Geological Survey, have the following average composition: 48.74 percent $\mathrm{A}_{2} \mathrm{O}_{3}, 2.84$ percent $\mathrm{Fe}_{2} \mathrm{O}_{3}, 2.06$ percent $\mathrm{TiO}_{2}$, and 22.58 percent $\mathrm{SiO}_{2}$, with 23.14 percent ignition loss.

Lot 49. --The Reese mine is in the NE $\frac{1}{4} \mathrm{SE} \frac{1}{4}$ lot 49 , in a small hollow on the steep north side of a broad ravine. The pit is about 100 by $80 \mathrm{ft}$ in area and about $25 \mathrm{ft}$ deep. The bauxite remaining in the walls is hard and soft, brown to red, pisolitic and pebbly bauxite, locally very ferruginous. The south wall is mostly in clay. The ore mined was white bauxitic clay from which white pebbles and boulders of pisolitic bauxite were screened after drying. Altitude $855 \mathrm{ft}$.

There is a small trench $200 \mathrm{ft}$ south of the mine that cuts pebbly bauxite in a matrix of bauxitic clay. One large boulder of hard mottled brown pisolitic bauxite is exposed. The openings are not extensive enough to define the limits of this deposit.

Lot 53. - The Broadaway (Bigelow) mine is in the middle of the $S W \frac{1}{4}$ lot 53 , on the crest and upper west side of a ridge. The more easterly of two contiguous pits is funnel-shaped, about $100 \mathrm{ft}$ across and $30 \mathrm{ft}$ deep. The south and west walls contain white amorphous bauxitic clay, locally with pebbles of white bauxite. The other walls show residual clay near the top and fire clay near the bottom. The more westerly pit is 175 by $75 \mathrm{ft}$ in area and $15 \mathrm{ft}$ deep. The north wall exposes soft white bauxitic clay, some with pebbles and small boulders of bauxite; hard brownish vesicular bauxite locally overlies this bauxitic clay. Test holes in the pit floor penetrated bauxite. Altitude 960-980 ft.

Lot 56. - - A prospect in the northwest corner of lot 56 lies on the south side of a broad depression. It consists of a 10 by $50 \mathrm{ft}$ trench and a test hole $20 \mathrm{ft}$ away, both in clayey red and white oolitic bauxite. Several other adjacent pits show no bauxite. Altitude $890 \mathrm{ft}$.

Lot 59. --The Whorton (Mitchell) mine lies on the south slope of a high hill in the SE $\frac{1}{4} \mathrm{NW}^{\frac{1}{4}}$ lot 59 . The pit is 75 by $120 \mathrm{ft}$ in area and 10-25 ft deep. The north and west walls expose pink to white amorphous bauxitic clay, grading into soft pisolitic bauxite with pebbles and boulders of harder white pisolitic bauxite. The ore mined was massive white oolitic bauxite (Watson, 1904, p. 108), a sample of which contained 57.73 percent $\mathrm{A}_{2} \mathrm{O}_{3}, 1.12$ percent $\mathrm{Fe}_{2} \mathrm{O}_{3}$, 5.35 percent $\mathrm{TiO}_{2}$, and 5.10 percent $\mathrm{SiO}_{2}$. Altitude $950 \mathrm{ft}$.

Just north of the public road, $300 \mathrm{ft}$ southwest of the mine, fragments of hard white pisolitic bauxite are strewn around a small pit. Adjacent test holes show none.

The Maggie Burkhalter prospect is in the $S E \frac{1}{4} \mathrm{NE} \frac{1}{4}$ lot 59 , on the east side of the crest of a broad ridge. A shallow pit 20 by $40 \mathrm{ft}$ across and two test holes $75 \mathrm{ft}$ to the south have fragments of white pisolitic bauxite scattered around them. A test hole $50 \mathrm{ft}$ west of the pit contains white fire clay. None of the many other holes in the vicinity show any bauxite. Altitude $880 \mathrm{ft}$.

Lot 60. --A prospect in the NW $\frac{1}{4} N_{W}^{\frac{1}{4}}$ lot 60 lies at the base of the slope on the east side of a broad valley. There are at least 10 shallow test holes and one pit 10 by $15 \mathrm{ft}$ across. The pit and a hole $25 \mathrm{ft}$ to the west have a little very hard bauxite scattered around the openings, and fire clay in the walls. A sample of bauxite from this prospect, analyzed by the Georgia Geo̊logical Survey, contained 60.14 per- 
cent $\mathrm{Al}_{2} \mathrm{O}_{3}, 3.33$ percent $\mathrm{Fe}_{2} \mathrm{O}_{3}, 2.25$ percent $\mathrm{TiO}_{2}$, and 4.46 percent $\mathrm{SiO}_{2}$, with an ignition loss of 29.72 percent. Other test holes adjacent to and collectively surrounding these two openings expose cherty residual clay. Altitude $815 \mathrm{ft}$.

Lot 84.--The Erwin prospect is in the SW $\frac{1}{4} \mathrm{SW} \frac{1}{4}$ lot 84 , on the lower slopes west of a narrow shallow ravine. Many deep closely spaced test holes, mostly put down under the direction of the Georgia Geological Survey, indicate that a narrow area $50 \mathrm{ft}$ long is underlain by bauxite, and a slightly larger area includes several pits with fire clay. The bauxite is white bauxitic clay with a small proportion of boulders of light-colored hard bauxite with large and small pisolites. Altitude $840 \mathrm{ft}$.

Lot 86. - A test hole in the northwest corner of lot $\overline{86, \text { on }}$ the steep northeast slope of a ridge, exposes massive white soft coarsely vesicular bauxite. Adjacent holes show none.

\section{Section 4, district 3}

Lot 534. --The Little Lamb prospect lies in the $\mathrm{S} \frac{1}{2} \mathrm{SE} \frac{\frac{1}{4} \operatorname{lot} 534}{\text {, }}$ on the lower southwest slope of a high knob. A test hole $10 \mathrm{ft}$ deep contains cherty clay with some pebbles and boulders of white pisolitic bauxite. Shallow holes surrounding this opening show only cherty clay. Up the slope $100 \mathrm{ft}$ northeast, four shallow test holes in an area $100 \mathrm{ft}$ across reveal pink and ferruginous bauxitic clay with a few boulders of hard red pisolitic bauxite. Altitude $870 \mathrm{ft}$.

Lot 535. --The Bobo mine lies at the west end of a ravine, just east of a saddle, in the SE $\frac{1}{4}$ lot 535. It is a pit 80 by $175 \mathrm{ft}$ in area, and Watson (1904, p. 95) estimated that the depth of ore was 55-70 ft. Only chert and a little fire clay now show in the walls. Watson (1904, p. 96) describes the ore as soft white pebbly bauxite, locally with red boulders of hard pisolitic bauxite. Five samples contained an average of 60.50 percent $\mathrm{Al}_{2} \mathrm{O}_{3}, 0.91$ percent $\mathrm{Fe}_{2} \mathrm{O}_{3}, 4.51$ percent $\mathrm{TiO}_{2}, 3.87$ percent $\mathrm{SiO}_{2}$, and 31.26 percent $\mathrm{H}_{2} \mathrm{O}$. Altitude $915 \mathrm{ft}$.

Two hundred feet west of the mine is a small shallow pit about 25 by $40 \mathrm{ft}$ in area, with slumped walls. Some white oolitic and pisolitic bauxite and one boulder of hard siliceous bauxite lie just west of the opening.

Lot 536. --The Lanham prospect is in the SW $\frac{1}{4}$ lot 536 , on the north side of a small narrow ravine. Several test holes, including one 18 and another $15 \mathrm{ft}$ deep, partly block out an area $75 \mathrm{ft}$ across that is underlain by bauxite. The openings expose pebbles and boulders of white pisolitic bauxite in soft white bauxitic clay. Altitude $860 \mathrm{ft}$.

Lot 549.--The Washington prospect, in the middle of the $N \frac{1}{2} N W \frac{1}{4}$ lot 549 , is on the south side and near the head of a small ravine. There are several shallow test holes in residual clay and one deeper one in hard cream-colored bauxite with large pisolites. Altitude $900 \mathrm{ft}$.

Lot 551. - The Woods mine is in the NE $\frac{1}{4} \mathrm{NW} \frac{1}{4}$

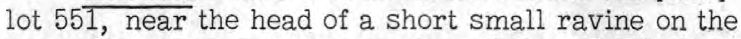
east side of a broad deep ravine. It is a pit about
100 by $30 \mathrm{ft}$ in area and $15 \mathrm{ft}$ deep, with some soft white pebbly bauxite exposed in the south wall. The deposit does not seem to be blocked out. According to Watson (1904, p. 98), the ore contained boulders of hard buff pisolitic bauxite. An analysis of the ore shows the following composition: 62.68 percent $\mathrm{Al}_{2} \mathrm{O}_{3}$, 0.52 percent $\mathrm{Fe}_{2} \mathrm{O}_{3}, 4.70$ percent $\mathrm{TiO}_{2}, 1.30$ percent $\mathrm{SiO}_{2}$, and 30.80 percent $\mathrm{H}_{2} \mathrm{O}$. Altitude $855 \mathrm{ft}$.

Lot 552. --The Hatch prospect lies on the lower west slope of a broad deep ravine, in the middle of the $\mathrm{SE} \frac{1}{4}$ lot 552. Fragments of white amorphous and pisolitic bauxite are scattered around two of four holes in an east-west line, all slumped and overgrown. Altitude $815 \mathrm{ft}$.

Lot 606. --The Red Warrior mine crosses the east line of the $\mathrm{NE}^{\frac{1}{4}}$ lot 606 , in the middle of the west slope of a high ridge. The pit is $100 \mathrm{ft}$ long, $20-30 \mathrm{ft}$ wide, and about $20 \mathrm{ft}$ deep in the deepest part. The walls show mostly massive, medium-hard, coarsely pisolitic mottled red and yellow bauxite with scattered red boulders. The deposit is far from worked out, but most of the material mined from the pit has evidently gone on the dump. Watson (1904, p. 95) gives three analyses, which average 55.06 percent $\mathrm{A}_{2} \mathrm{O}_{3}, 7.12$ percent $\mathrm{Fe}_{2} \mathrm{O}_{3}, 4.45$ percent $\mathrm{TiO}_{2}, 1.83$ percent $\mathrm{SiO}_{2}$, and 32.33 percent $\mathrm{H}_{2} \mathrm{O}$. Altitude $865 \mathrm{ft}$.

Lot 607.--The Fat John mine lies up the slope $100 \mathrm{ft}$ east of the Red Warrior mine in the NW $\frac{1}{4}$ lot 607. The pit is $200 \mathrm{ft}$ long, $75 \mathrm{ft}$ wide, and $35 \mathrm{ft}$ deep at the east end; both the Fat John and Red Warrior mines are elongate east-west and lie on the same east-west line. The northwest part of the Fat John pit shows a little pebbly bauxite and pink amorphous clay, but the walls in the rest of the pit show only fire clay and residual clay. According to Watson (1904, p. 94), the ore was dense buff pisolitic bauxite, and the pisolites had powdery red nuclei. An analyzed sample contained 61.31 percent $\mathrm{A}_{2} \mathrm{O}_{3}, 1.04$ percent $\mathrm{Fe}_{2} \mathrm{O}_{3}, 4.58$ percent $\mathrm{TiO}_{2}, 1.40$ percent $\mathrm{SiO}_{2}$, and 31 . To percent $\mathrm{H}_{2} \mathrm{O}$. Altitude $905 \mathrm{ft}$.

Lot 615.--The Howell mine lies in the bottom of a deep ravine in the northwest corner of lot 615. The roughly circular pit is about $100 \mathrm{ft}$ across and was probably $25 \mathrm{ft}$ deep before slumping. Most of the walls are in cherty clay, but there is a solid mass of brittle., hard, white pisolitic bauxite on the east side and some soft red-stained pebbly bauxite with boulders of hard buff pisolitic bauxite on the south side. Fire clay everywhere separates bauxite from residual clay. Test holes adjacent to the pit are all in cherty clay, but are not abundant enough to block out the deposit completely. Altitude $895 \mathrm{ft}$.

Lot 616. - There is a test hole $8 \mathrm{ft}$ across in a saddle atop a ridge in the $\mathrm{NE}^{\frac{1}{4}} \mathrm{NE} \frac{1}{4}$ lot 616 . A little amorphous white bauxite and some boulders of hard gray bauxite with ferruginous and light-colored pisolites are scattered around the opening. Altitude $980 \mathrm{ft}$.

Lot 677. --See under lot 692.

Lot 678. --There is a small prospect in the northeast corner of the SW $\frac{1}{4}$ lot 678 , on the west side of a steep narrow ravine near its head. Fragments of white pisolitic bauxite are scattered around several 
shallow test holes within an area a few feet square. Altitude $930 \mathrm{ft}$.

Lot 687. --The Minter prospect lies on the north side of a small shallow ravine, near its head, in the $\mathrm{SE} \frac{1}{4} \mathrm{NW} \frac{1}{4}$ lot 687 . Abundant white pisolitic and pebble bauxite is scattered around a test hole that was originally $30 \mathrm{ft}$ deep. The walls show soft and hard white bauxite, and some bauxitic clay and cherty clay. Some additional holes $50 \mathrm{ft}$ away to the north, west, and east are all in residual clay. Another hole still farther away to the west shows purple ferruginous clay, and a test-hole $75 \mathrm{ft}$ southeast shows mostly cherty clay with a little fire clay and a few pebbles of bauxite. Altitude $885 \mathrm{ft}$.

Lot 691. --The Hyram Bobo prospect, in the $S E \frac{1}{4} S \bar{W} \frac{1}{4}$ lot 691 , lies just north of the bottom of Booger Hollow. Over 50 test holes, including 30 put down under the direction of the Georgia Geological Survey, outline an irregular area of about 20,000 sq ft underlain by bauxitic clay; within this area are two patches $150 \mathrm{ft}$ apart, probably totaling 4,000 sq ft, that contain soft to hard white bauxite with pink and white pisolites. A pit was being opened in each of. these two bauxite patches in 1942. A 5-foot channel sample collected by the writers from the more southerly pit contained 51.38 percent $\mathrm{Al}_{2} \mathrm{O}_{3}, 1.58$ percent $\mathrm{Fe}_{2} \mathrm{O}_{3}$, 3.66 percent $\mathrm{TiO}_{2}$, and 13.20 percent $\mathrm{SiO}_{2}$, and a 4-foot sample from the other pit contained 47.22 percent $\mathrm{Al}_{2} \mathrm{O}_{3}, 4.52$ percent $\mathrm{Fe}_{2} \mathrm{O}_{3}, 4.00$ percent $\mathrm{TiO}_{2}$, and 16.53 percent $\mathrm{SiO}_{2}$. The area enclosing the bauxite patches contains pink and white bauxitic clay with scattered pebbles of white bauxite. The pebbles probably make up 5-10 percent of the volume of this material, and contain an average of 55.34 percent $\mathrm{A}_{2} \mathrm{O}_{3}, 2.28$ percent $\mathrm{Fe}_{2} \mathrm{O}_{3}, 3.67$ percent $\mathrm{TiO}_{2}$, and 8.46 percent $\mathrm{SiO}_{2}$. The clay and pebbles combined contain about 43 percent $\mathrm{Al}_{2} \mathrm{O}_{3}$, and 30 percent $\mathrm{SiO}_{2}$. Many pits surrounding the area of bauxitic clay show only fire clay and cherty clay. This deposit represents a northerly extension of the main Booger-Hollow deposit in lot 750. Altitude $835 \mathrm{ft}$.

Lot 692. --There are two deep test holes $50 \mathrm{ft}$ apart on the steep south slope at the south end of a high ridge, on both sides of the north line of lot 692 . The northeastern pit is in very ferruginous pisolitic bauxite with clay and halloysite. The other contains red to pink coarsely vesicular bauxite, grading down into whiter bauxite. Shallower holes in the vicinity exposed no bauxite. Altitude $860 \mathrm{ft}$.

Lot 748. --An old test hole, now filled in, lies in the center of the $\mathrm{NE}^{\frac{1}{4}}$ lot 748 , on the southwest slope of a hill. An area of red clay $50 \mathrm{ft}$ square is littered with small pebbles and boulders of white pisolitic bauxite.

Lot 750.--The very large Booger Hollow mine lies in the bottom of Booger Hollow in the $\mathrm{NE}^{\frac{1}{4}} \mathrm{NW}^{\frac{1}{4}}$ lot 750 . The main pit is 250 by $200 \mathrm{ft}$ in extent and was over $45 \mathrm{ft}$ deep; a smaller pit lies $150 \mathrm{ft}$ northwest. Total production from the two pits was about 60,000 tons. Above the present water line, the walls of the main pit contain a little fire clay on the south side, and gravel and residual clay elsewhere. The walls of the bauxite mass are steep, and near the center of the body there was a pipe-like mass of lignite up to $25 \mathrm{ft}$ across. This lignite mass extends downward at least to the bottom of the pit. Fragments of the lignite collected from the dump by R. W. Brown were found to contain plant fossils of Eocene or older age (Bridge, 1950, p. 194; Cloud and Brown, 1944, p. 1466). The ore from the main pit was hard light-colored pebbly and pisolitic bauxite. Ore from the smaller pit was hard and soft, pink to white pisolitic bauxite. Altitude $830 \mathrm{ft}$.

Lot 756. --A prospect that crosses the west boundary of the SW $\frac{1}{4}$ lot 756 lies on the lower southern slope of a broad deep ravine. Many test holes and a pit $20 \mathrm{ft}$ across outline a bauxite deposit at least 100 by $50 \mathrm{ft}$ in extent. Medium hard to hard massive white pisolitic bauxite is scattered around the pit, and the test holes expose red bauxitic clay. Altitude $870 \mathrm{ft}$.

Lot 765. --There was a prospect in the middle of the $W \frac{1}{2} S E \frac{1}{4}$ lot 765 , at the base of the south slope of a low hill. Large and small fragments of white pisolitic bauxite are scattered on the surface at the site of some old test holes, now filled in. Local residents report that augering failed to disclose an ore body here. Altitude $790 \mathrm{ft}$.

Lot 820.--The New Prospect mine is in the $\mathrm{SE} \frac{1}{4} \mathrm{NW} \frac{1}{4}$ lot 820 , at the base of the northwest slope of a hill, beside the public road, The walls of a shallow pit, 50 by $60 \mathrm{ft}$ in area, locally contain boulders of light pisolitic bauxite with crumbly red pisolites, and some soft white bauxitic clay with red pisolites. Red clay is more abundant than bauxite. Altitude $790 \mathrm{ft}$.

The Moseley mine is in the SW $\frac{1}{4} \mathrm{SE} \frac{1}{4}$ lot 820 , on the south slope of a low ridge, The pit is 200 by $100 \mathrm{ft}$ in area, with a smaller opening extending $50 \mathrm{ft}$ east from the south end of the main pit. The walls contain pebbles and boulders of white pisolitic bauxite in a matrix of soft white bauxitic clay. There is one test hole in bauxite up the slope just east of the pit. Altitude $835 \mathrm{ft}$.

Lot 824. --The Clarence Reynolds (Lewis Reynolds) prospect, in the southwest corner of lot 824, lies at the base and part way up the steep east slope of a ridge. There is one large test hole in rather massive hard pink and white pisolitic bauxite. An area about $100 \mathrm{ft}$ across is strewn with fragments of this material. Altitude $835 \mathrm{ft}$.

Lot 830.--A prospect in the W $\frac{1}{2}$ SW $\frac{1}{4}$ lot 830 lies on a very gentle surface sloping south. Numerous test holes partly define a deposit, possibly $100 \mathrm{ft}$ across, of dark red very ferruginous bauxite. Altitude $840 \mathrm{ft}$.

Lot 841. --The Berkstressor manganese prospect is in the southeast corner of lot 841, just outside the area covered by figure 2. It lies on a gentle slope on the upper southeast side of a ridge. The owner states that bauxite was encountered below manganiferous clay at depths of 20-30 ft in three or four test holes, but no fragments were found lying around on the surface.

Lot 891. --The most northerly of the Burkhalter prospects is in the SW $\frac{1}{4} \mathrm{NE} \frac{1}{4}$ lot 891 , at the base of the west slope of a small low hill. Fragments and boulders of red pisolitic bauxite are scattered around three test holes in a narrow area about $100 \mathrm{ft}$ long from north to south. Altitude $790 \mathrm{ft}$. 
In the SW $\frac{1}{4} \mathrm{SE} \frac{1}{4}$ lot 891 , on the gentle north slope of a low ridge, fragments of very white soft clayey bauxite with a few brown pisolites are scattered around an old filled-in test hole. Altitude $800 \mathrm{ft}$.

In the $\mathrm{SE} \frac{1}{4} \mathrm{SE} \frac{1}{4}$ lot 891 , on the same slope and $250 \mathrm{ft}$ east of the last opening, there are at least two old filled-in test holes about $50 \mathrm{ft}$ apart. Fragments of hard white pisolitic bauxite and some red ferruginous bauxite are scattered on the surface. Altitude $810 \mathrm{ft}$.

Lot 892. --There is a prospect in the NW $\frac{1}{4} \mathrm{SW}^{\frac{1}{4}}$ lot 892 , just south of the lower end of a ravine at the western base of a ridge. Eight test holes block out a deposit, at least $75 \mathrm{ft}$ across, of hard red bauxite with crumbly pisolites. Altitude $800 \mathrm{ft}$.

Lot 896. --The Willis Reynolds prospect is in the middle of the western edge of the $\mathrm{SW} \frac{1}{4}$ lot 896 , on the lower slope south of a ridge and just north of a public road. There are two small slumped test holes, around one of which is scattered soft clayey pink and white bauxite with pebbles and boulders of harder white pisolitic bauxite. Altitude $790 \mathrm{ft}$.

Lot 905. --The Doyle mine, in the NW $\frac{1}{4} N W \frac{1}{4}$ lot 905 , lies at the western base of a ridge. A pit 30 by $50 \mathrm{ft}$ in area shows a little fire clay in its walls. According to Watson (1904, p. 103), the ore was soft white pebble bauxite with a few red pebbles. He gives the following analysis: 52.31 percent $\mathrm{Al}_{2} \mathrm{O}_{3}, 1.12$ percent $\mathrm{Fe}_{2} \mathrm{O}_{3}, 2.08$ percent $\mathrm{TiO}_{2}, 19.56$ percent $\mathrm{SiO}_{2}$, and 24.21 percent $\mathrm{H}_{2} \mathrm{O}$. Altitude $785 \mathrm{ft}$.

Lot 910. --The Henry mine is just south of the center of lot 910 on the south side and bottom of a small deep ravine. An area 120 by $200 \mathrm{ft}$ in extent has been stripped to a depth of a few feet and about 4, 000 tons of bauxite removed. Adjacent test holes indicate that bauxite extends beyond the stripped area. Hard dark red pisolitic bauxite with crumbly red pisolites is interlayered with pink to cream-oolored bauxitic clay with a few ferruginous pisolites. The layers are a few inches to $8 \mathrm{ft}$ in thickness and dip in the same direction but more steeply than the surface slope. Watson (1904, p. 99) mentions a $40-\mathrm{ft}$ shaft at this deposit that penetrated bauxite for its entire depth, so the deposit is far from exhausted. He gives 5 analyses, which average 58.21 percent $\mathrm{A}_{2} \mathrm{O}_{3}, 8.02$ percent $\mathrm{Fe}_{2} \mathrm{O}_{3}$, and 4.50 percent $\mathrm{SiO}_{2}$. Altitude $855 \mathrm{ft}$.

A filled-in test hole in the NW $\frac{1}{4} \mathrm{NE} \frac{1}{4}$ lot 910 lies on the north side of a deep gully. Bauxitic clay with pebbles and small boulders of hard white pisolitic bauxite are scattered around the site of the hole. Altitude $790 \mathrm{ft}$.

Lot 973. --Several small test holes and some auger holes were put down in a broad valley bottom in the NE $\frac{1}{4}$ lot 973. A little hard white bauxite with much halloysite and a few pisolites lies beside one of the holes.

\section{Cave Spring district}

Section 4, district 2

Lot 214. --The Hampton (Hebble) mine is on the lower southeastern slope of a high hill in the SW $\frac{1}{4} \mathrm{SW} \frac{1}{4}$ lot 214 . The main pit is 150 by $250 \mathrm{ft}$ in area and at least $60 \mathrm{ft}$ deep. The walls contain fire clay and cherty clay, for the most part, but there is a little soft ferruginous pisolitic bauxite at the west end. The ore consisted of boulders and masses of hard white pisolitic bauxite with minor soft bauxite between. The pisolites range from reddish and crumbly to white and hard. A small pit adjoining the main pit on the northwest side has completely slumped walls. Altitude $940 \mathrm{ft}$.

\section{Section 4, district 3}

Lot 560. --The Davis mine lies on the south side of a hilltop in the middle of the west edge of lot 560 . It is a pit about $50 \mathrm{ft}$ across and $15 \mathrm{ft}$ deep, whose walls show only residual clay. On the basis of material scattered around the opening, the ore apparently consisted of boulders of hard pinkish pisolitic bauxite in white bauxitic clay. Bauxite is also scattered around a small test hole $100 \mathrm{ft}$ southwest of the main pit.

Lot 1017.--A small mine in the $S \frac{1}{2} \mathrm{NE} \frac{1}{4}$ lot 1017 is on the north side of a bench extending east from a high ridge. A bowl-shaped pit $130 \mathrm{ft}$ across and $30 \mathrm{ft}$ deep shows mostly red clay and a little bauxitic clay in its walls. Cherty clay is exposed near the bottom. The bauxite is soft and reddish brown, with imperfect crumbly pisolites and boulders of very pisolitic hard red-brown bauxite. Altitude $945 \mathrm{ft}$.

Lot 1018. --The Culbertson mine is in the northwest corner of lot 1018, on the east edge of a bench extending east from a high ridge. A pit 80 by $60 \mathrm{ft}$ in area and $30 \mathrm{ft}$ deep shows only red residual clay with a few pieces of bauxite in its slumped walls. According to Watson $(1904$, p. 93) the ore was pink oolitic bauxite, and partial analyses showed an alumina content ranging from 39.75 to 49.80 percent. Altitude $920 \mathrm{ft}$.

It should be noted that Watson's description (1904, pp. 91-93) of the Culbertson mine, and of the Gordon and Penny mines (see below), places each mine one lot farther north than the present writers. The Culbertson, Gordon, and Penny mines described here are certainly the same as the Culbertson, Gordon, and Penny deposits of Watson; the identities may be clearly established from Watson's descriptions of topographic position and altitude.

Lot 1072. --The Gordon mine lies in the SW $\frac{1}{4} \mathrm{NE}^{\frac{1}{4}}$ lot 1072 (see comment under lot 1018), at the base and on the lower west wall of a deep ravine. The pit is large and shallow, much slumped, and about $150 \mathrm{ft}$ across in its north-south dimension. The walls show cherty clay and a little fire clay. The bauxite on the dump is soft to hard, white, and pisolitic. Altitude $875 \mathrm{ft}$.

Lot 1089. --The Penny mine is near the bottom of a steep slope on the east side of the same ravine that contains the Gordon mine (see above). It lies in the middle of the south edge of lot 1089. A pit 50-75 ft wide has been driven southeast $100 \mathrm{ft}$ into the slope, and the back wall is about $30 \mathrm{ft}$ high. The walls expose mostly residual clay, and a little fire clay. Some bauxitic clay with pebbles and boulders of white pisolitic bauxite is exposed at the west end. The fire clay appears to dip under the bauxite. Altitude $785 \mathrm{ft}$. 
Lot 1158.--There are several small test holes at the eastern base of Griffith ridge, in the $W \frac{1}{2} S E \frac{1}{4}$ lot 1158. Two of the pits, $40 \mathrm{ft}$ apart, show pink and white bauxite with imperfect oolites. Altitude $750 \mathrm{ft}$.

Lot 1220.--The Reese mine lies in the $\mathrm{N} \frac{1}{2} \mathrm{SE} \frac{\frac{1}{4}}{\mathrm{lot}} 1220$, on the lower north wall of a deep ravine draining northeast. A pit $100 \mathrm{ft}$ across and $25 \mathrm{ft}$ deep lies $100 \mathrm{ft}$ north of a smaller pit. The walls of both openings consist mostly of ferruginous clay. There is a little soft porous pink bauxite with dark red pisolites in the larger pit, and a little red bauxite is scattered around test holes adjacent to this pit. There is some hard and soft pisolitic bauxite exposed in the northwest corner of the smaller pit. The dumps contain many boulders of hard dark red ferruginous bauxite. Altitude $840 \mathrm{ft}$.

Lot 1229. --The Fite prospect lies atop a high ridge in the $S \frac{1}{2} N E \frac{1}{4}$ lot 1229. Two deep holes $20 \mathrm{ft}$ apart show pink to white pisolitic to coarsely vesicular bauxite. The ore is rather massive, with some hard boulders and some white fire clay. A commercial analysis made for the owner gave the following composition: 52.10 percent $\mathrm{Al}_{2} \mathrm{O}_{3}, 27.84$ percent $\mathrm{SiO}_{2}$, and 0.65 percent $\mathrm{Fe}_{2} \mathrm{O}_{3}, 19.5$ percent ignition loss. Surrounding test holes show no bauxite. Altitude $920 \mathrm{ft}$.

Lot 1230.--A fairly large deposit has been explored just south of the center of lot 1230, in the bottom of a shallow ravine on the lower east slope of a high ridge. One shaft about $35 \mathrm{ft}$ deep with three tunnels, and several shallow pits and test holes block out an area about 250 by $50 \mathrm{ft}$ in area that contains bauxitic material. The excavated material on the surface is mostly bauxitic clay with a few pisolites. A hole at the east end of the area exposed a little coarsely vesicular bauxite. Altitude $800 \mathrm{ft}$.

\section{Section 4, district 16}

Lot 397.--The Simmons prospect lies near the bottom of the gentle north slope of a high ridge in the $\mathrm{NE}_{\frac{1}{4}} \mathrm{SE}^{\frac{1}{4}}$ lot 397. There are several small test holes and auger holes, and one large shaft about $22 \mathrm{ft}$ deep with a 20 -foot tunnel to the south. The exposures suggest a deposit about 75 by 50 ft in extent, probably including a substantial amount of clay. The bauxite from the shaft is soft, pink, and pisolitic. Altitude $830 \mathrm{ft}$.

$\underline{\text { Scattered deposits of southeastern Floyd County }}$ and southwestern Bartow County

Section 3, district 17

Lot 206. -- The Carroll (Martin) prospect, in the SW $\frac{1}{4} \mathrm{NW} \frac{1}{4}$ lot 206, lies in the bottom of a small shallow swale. It has been explored by several deep and shallow test holes, all of which are now filled with debris, and a number of auger holes. The owner's description of these openings limits the possible extent of the deposit to an area about $100 \mathrm{ft}$ across. Boulders and pebbles of hard white pisolitic bauxite are strewn over a small area around one of the holes. Altitude about $730 \mathrm{ft}$.

A cistern dug about $650 \mathrm{ft}$ south of the prospect encountered boulders of hard red pisolitic bauxite in a matrix of pink and white fire clay at depths of $15-30 \mathrm{ft}$, according to the owner; he also states that auger holes put down around the cistern failed to reveal significant extensions of the deposit.

Lot 571.--The Fountain prospect, in the NW $\frac{1}{4}$ lot 571, lies in a broad shallow swale. It has been explored by several test pits and about 40 auger holes. The owner's description of the results of this exploration suggest that an area of 175 by $250 \mathrm{ft}$ may be underlain by bauxite to a maximum depth of $40 \mathrm{ft}$. Several of the test holes reveal massive pinkish-white vesicular bauxite with many imperfect crumbly dark-red pisolites. Altitude about $775 \mathrm{ft}$.

Section 3, district 22

Lot 109.--The Evans prospect lies in the $\mathrm{NE} \frac{1}{4} \mathrm{SE} \frac{1}{4}$ lot 109 , across the bottom of a shallow ravine. A shallow pit northeast of the watercourse exposes massive light gray bauxite with large deep-reddish-brown crumbly pisolites. Under a bridge $150 \mathrm{ft}$ southwest of the pit, the stream has exposed coarsely pisolitic bauxite boulders in a whitish gray bauxitic matrix. On the south side of the highway, $75 \mathrm{ft}$ south of the bridge, a roadcut exposes pink and white bauxitic clay. Two samples from the Evans prospect, analyzed by the Georgia Geological Survey, have the following average composition: 42.74 percent $\mathrm{A}_{2} \mathrm{O}_{3}$, 19. 15 percent $\mathrm{Fe}_{2} \mathrm{O}_{3}, 1.75$ percent $\mathrm{TiO}_{2}$, and 13.26 percent $\mathrm{SiO}_{2}$, with an ignition loss of 23.35 percent. Altitude $750 \mathrm{ft}$.

Lot 110.--The Kirkland (M. B. Woods) mine is in the NE $\frac{1}{4} \mathrm{SW} \frac{1}{4}$ lot 110 , on the lower east slope of a high ridge. A semicircular pit 100 by $50 \mathrm{ft}$ in area is cut into the slope; it was originally about $38 \mathrm{ft}$ deep, but has since become almost half filled by slump and detritus. The south and west walls of the pit expose white crumbly pisolitic bauxite and laminated pink and white bauxitic clay, overlain by $8-12 \mathrm{ft}$ of chert and sandy clay. A shipment of 26 carloads had an average composition of 50.84 percent $\mathrm{Al}_{2} \mathrm{O}_{3}$, 0.26 percent $\mathrm{Fe}_{2} \mathrm{O}_{3}$, and 24.16 percent $\mathrm{SiO}_{2}$, according to analyses made by the Detroit Chemical Company in 1913 (Document in hands of owner). Two of five auger holes put down in the floor of the pit by the Bureau of Mines penetrated siliceous bauxite (Lewiecki, 1949), but the greater part of this bauxite may be part of the debris filling.

Lot 129.--The Bradshaw (Bonsack) mine lies in the SE $\frac{1}{4} \mathrm{NE} \frac{1}{4}$ lot 129, in the bottom of a broad valley. During 1941-42, 12 carloads of ore were shipped for use in the manufacture of refractory brick. The pit was 175 by $60 \mathrm{ft}$ in area, elongate northeast, and $30 \mathrm{ft}$ deep 
when visited in 1942. Most of the walls contained boulders and pebbles of dark red and grayish white pisolitic bauxite in a matrix of red and white bauxitic clay. Both ends of the pit cut sandy residual clay. Test holes put down under the direction of the Geological Survey of Georgia indicate that the ore body is about 175 by $100 \mathrm{ft}$ in area, with residual clay beyond on all sides. Test holes in the bottom of the pit at both ends indicate that ore continues at least $20 \mathrm{ft}$ below the bottom. Watson (1904, p. 110) gives the following analyses of ore from this mine:

\begin{tabular}{rrrrr}
\hline $\mathrm{A}_{2} \mathrm{O}_{3}$ & $\mathrm{Fe}_{2} \mathrm{O}_{3}$ & $\mathrm{TiO}_{2}$ & $\mathrm{SiO}_{2}$ & $\mathrm{H}_{2} \mathrm{O}$ \\
\hline Red ore --52.40 & 12.60 & 3.70 & 3.95 & 27.35 \\
Light ore -56.96 & 1.69 & 4.05 & 6.03 & 31.40 \\
\hline
\end{tabular}

The ore shipped in 1941-42 contained considerable clay. Altitude $790 \mathrm{ft}$.

This deposit is of interest as an exception to the general rule that bauxite occurs only in areas underlain by the Knox group. The clays that contain this bauxite body were almost certainly derived from carbonate rocks of the upper part of the Conasauga formation rather than the dolomite of the Knox group. Cherty residual clays of the Knox are found on the ridge a half mile farther east.

Lot 150.--The Fomby mine lies atop a low knoll in the $\mathrm{NE} \frac{1}{4} \mathrm{SW} \frac{1}{4}$ lot 150 . The pit is about $55 \mathrm{ft}$ across and 10-15 ft deep. The north and south walls contain soft white bauxitic clay and large masses of vesicular bauxite with imperfectly rounded cavities. Material on the dump includes pebbles and boulders of hard white pisolitic bauxite. An average of six analyses published by Watson (1904, p. 109) gives the following composition: 61.0 percent $\mathrm{A}_{2} \mathrm{O}_{3}, 4.0$ percent $\mathrm{Fe}_{2} \mathrm{O}_{3}$, and 2.5 percent $\mathrm{SiO}_{2}$. Watson says that the ore extends downward at least $35 \mathrm{ft}$. Altitude $790 \mathrm{ft}$.
Lot 151.--The Ritch prospect is in the NW $\frac{1}{4} S W^{\frac{1}{4}}$ lot 151, near the head of a gully on the lower west side of a prominent hill. Watson (1904, p. 108) mentions two pits, $150 \mathrm{ft}$ apart. The more northerly was $4 \mathrm{ft}$ deep and exposed white amorphous bauxite with scattered small imperfect oolites. The more southerly was $6 \mathrm{ft}$ deep, with a shaft in the bottom that cut hard ferruginous pisolitic bauxite. The pits are no longer evident (assuming the locality to be the same as that described by Watson), but boulders of hard ferruginous bauxite are scattered on the surface. Altitude $850 \mathrm{ft}$.

Lot 183.--The Cochran mine lies on the east side of the crest of a high ridge in the $\mathrm{NE}^{\frac{1}{4}} \mathrm{NW} \frac{1}{4}$ lot 183 . There is a pit, 100 by $45 \mathrm{ft}$ across and 10-15 ft deep, oriented eastward, and an adjacent stripped area 50 by $35 \mathrm{ft}$. Surrounding trenches and test holes have been filled. The pit walls are badly slumped, but the south wall exposes soft white amorphous bauxite and bauxitic clay with minor boulders and pebbles of hard pink and white bauxite. Maximum depth of ore below the bottom of the pit is $12 \mathrm{ft}$, according to local residents. Altitude $865 \mathrm{ft}$.

Lot 335.--The Brannon prospect lies near the head of a shallow swale draining west, in the middle of the west edge of the $S \frac{1}{2}$ lot 335 . Two shallow test holes 30 ft apart expose pebbles and boulders of hard ferruginous pisolitic bauxite in a matrix of reddish-brown clay. Altitude $860 \mathrm{ft}$.

\section{Section 3, district 23}

Lot 332.--The Freeman prospect is in the $\mathrm{SE} \frac{1}{4} \mathrm{SW} \frac{1}{4}$ lot 332 , on the lower west side of a deep narrow ravine. Several shallow pits expose a body of hard red pisolitic bauxite. Watson (1904, p. 113) gives the following analysis: 56.00 percent $\mathrm{A}_{2} \mathrm{O}_{3}, 9.64$ percent $\mathrm{Fe}_{2} \mathrm{O}_{3}$ and 6.31 percent $\mathrm{SiO}_{2}$. Surrounding test holes in chert, and sandy clay suggest that the deposit may be $50 \mathrm{ft}$ wide and 60-100 ft long. This deposit, at an altitude of $645 \mathrm{ft}$, is the lowest in the region. 
Akin Hermitage

Akin $-$ Berkstressor-_-_-_-_-_-_Bigelow

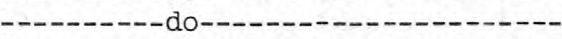
Bobo---_Bobo, Hyram-BonsackBooger Hollow-_....... Braden--- Bradshaw-Brannon--Branon-

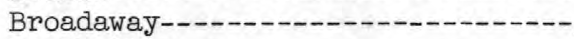

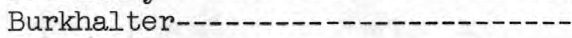
Burkhalter, Maggie-_._._. BurneyCarrollCherokee

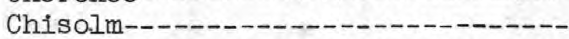

Church-

Clemmons------Cochran-ConneseenaBobo-

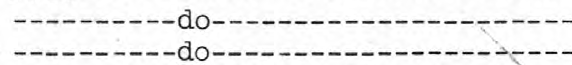

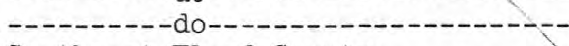
Southeast Floyd County-... Bobo----Hermitage-----------Southeast Floyd County--.-.--.--

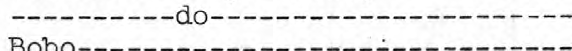
Bobo- - - - - - - do---- - - - - - - - - - -

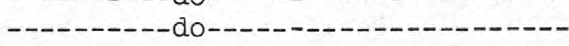
Hermitage-----Southwest Bartow County----.--Hermitage---- Southeast Floyd County.---.---Hermitage--_.-_Cave Spring-Curtis-Davis no. 1-Hermitage--.-Cave Spring---Hermitage--.-Davis no. 2-Discovery pit-Doyle-_. Drummond mine-1 Drummond prospect-Erwin--_-_Evans--.- Southeast Floyd County--.-Fat John-_._Felder-_.

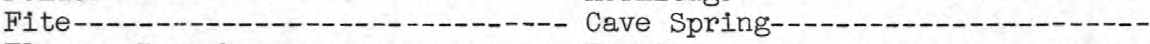
Flowery Branch-_._. Hermitage-_. Formby--. Southeast Floyd County-..-Fountain--.-Freeman--_- Southeast Floyd County--_-_Gilreath Hermitage--.-Gordon-Green---Grier-Hampton

HardeeHermitage--

HatchCave Spring---

Hatter

Hermitage------_--

Bobo -

Hawkins

Hermitage-_-_-

Hebble-

Henry---

Hight--.-

Holland--.-----

Holland Hill--.----

Holland House--

Holland SpringHowell

Cave Spring- do-

Bobo---- -

Hermitage--

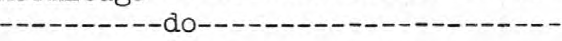

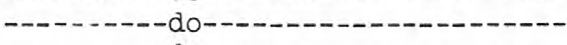
- - - - - - - - do-- - - - - - - - - - - - - - - - Julia-Kerce--KirklandBobo-rmitageKnowles - Southeast Floyd County--.--.--

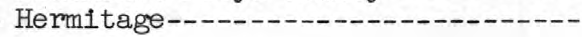

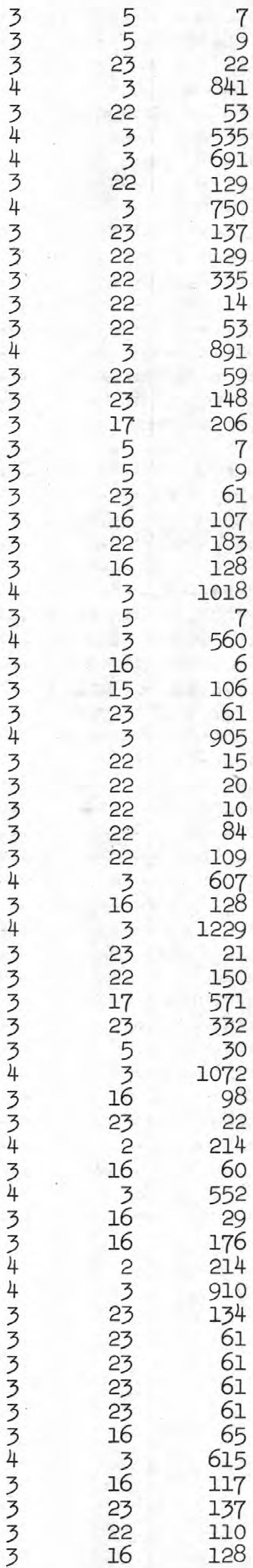


Lanham-- - - Lenning--------------

Little Lamb

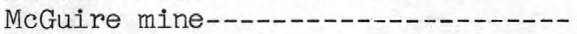

McGuire prospects---_-_-_-

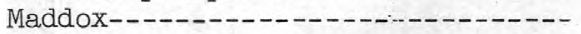

Martin---

Mary-

Merrimac--_--_-_-_-_-_-

Minter mines----

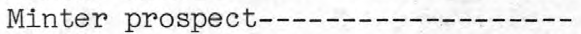

Mitchell-_--_-_-_-

Montague---

Morrow------

Moseley-

New Holland-

New Prospect-...-_...

North Hardee--_-_-_-_-

Otts-_-_-

Penny-- -

Perry--

Pinson--

Red Warrior-_.

Reese-0-- - - - - -

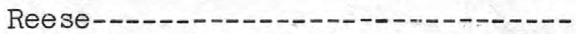

Reynolds, Clarence---.---_-.---

Reynolds, Lewis-_-_-_._-_._-_-

Reynolds, Willis-_-_-_.-_-_-

Ridge,Valley no, l-_.....

Ridge Valley no. 2---_-.-----

Ritch--_-_-

Scott--- - -

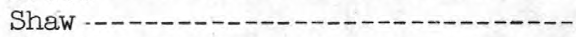

Sheets---

Simmons-

Spurlock---

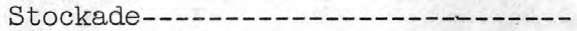

Terry-Shaw-_._-

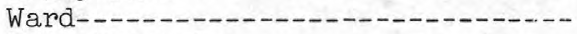

Ware Mountain-

Warner--.-_-.-...

Warring---

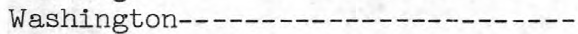

Washington, Bush-_-_-_-_-_-_--

Washington, Jeff--_-_-_-_-_---

Watters mine-----

Watters prospect------_-----

Whorton--

Woods---

Woods, M. B.--

Wright-
Bobo-Hermitage-- Bobo-_Hermitage--_--- - - do-- - - - - - - - - - - - - - - - - -

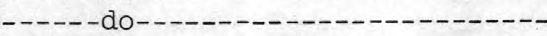
Southwest Bartow County-------Hermitage

-- - - do--

Bobo--

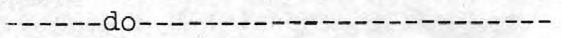

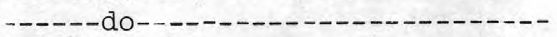

Hermitage--

-- - - do do-- - - - - - - - - - - - - -

Bobo--

Hermitage--

Bobo-- -

Hermitage--

Cave Spring--

Hermitagè--

Bobo- do-

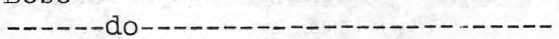

Cave Spring----

Bobo-c-

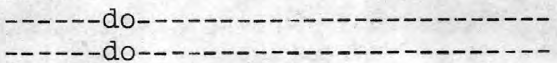

Hermitage--.--

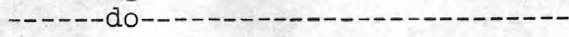

Southeast Floyd County---------

Hermitage------

- - - - do-- - - - - - - - - - - - - - - -

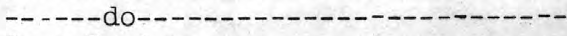

Cave Spring--0--

Hermitage----

Hermitage--

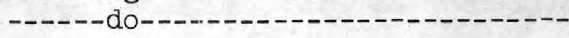

-- - - do-- - - - - - - - - - - - - - - - -

Bobo---- - -

He rmitage--.--

-

Bobo--

- - - do-- do-

Hermitage-......-

- - - - do--

Bobo--_-

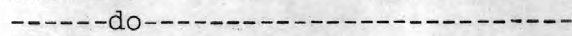

Southeast Floyd County--...--

Hermitage--_-_-_-

$\begin{array}{rrr}4 & 3 & 536 \\ 3 & 23 & 61 \\ 4 & 3 & 534 \\ 3 & 16 & 142 \\ 3 & 15 & 23 \\ 3 & 23 & 138 \\ 3 & 17 & 206 \\ 3 & 16 & 54 \\ 3 & 5 & 7 \\ 3 & 22 & 13 \\ 4 & 3 & 687 \\ 3 & 22 & 59 \\ 3 & 16 & 97 \\ 3 & 16 & 36 \\ 4 & 3 & 820 \\ 3 & 23 & 62 \\ 4 & 3 & 820 \\ 3 & 16 & 60 \\ 3 & 23 & 102 \\ 4 & 3 & 1089 \\ 3 & 23 & 147 \\ 3 & 15 & 31 \\ 4 & 3 & 606 \\ 3 & 22 & 49 \\ 4 & 3 & 1220 \\ 4 & 3 & 824 \\ 4 & 3 & 824 \\ 4 & 3 & 896 \\ 3 & 23 & 60,61 \\ 3 & 16 & 1 \\ 3 & 22 & 149 \\ 3 & 16 & 75 \\ 3 & 16 & 176 \\ 3 & 16 & 22 \\ 4 & 16 & 397 \\ 3 & 16 & 102 \\ 3 & 23 & 21 \\ 3 & 16 & 10,11 \\ 3 & 23 & 105 \\ 3 & 22 & 23 \\ 3 & 16 & 108 \\ 3 & 16 & 108 \\ 4 & 3 & 549 \\ 3 & 22 & 15 \\ 3 & 22 & 48 \\ 3 & 23 & 147 \\ 3 & 23 & 136 \\ 3 & 22 & 59 \\ 4 & 3 & 551 \\ 4 & 22 & 110 \\ 3 & 23 & 134\end{array}$




\section{REFERENCES CITED}

Adams, G. I., 1923, The formation of bauxite in sink holes: Econ. Geology, vol. 18, pp. 410-412.

Bridge, Josiah, 1950, Bauxite deposits of the southeastern United States: Proc. Symposium on Mineral Resources of the Southeastern U.S., Knoxville, Tennessee, pp. 170-201.

Butts, Charles, and Gildersleeve, Benjamin, 1948, Geology and mineral resources of the Paleozoic area in northwest Georgia: Georgia Geol. Survey Bull. 54, $176 \mathrm{pp}$.

Cloud, P. E., Jr., and Brown, R. W., 1944, Early Cenozoic sediments in the Appalachian region [Ala. and Ga. ] [abs. ]: Geol. Soc. America Bull. vol. 55, p. 1466.

Franke, H. A., and Trought, M. E., 1939, Bauxite and aluminum: Minerals Yearbook, 1939, pp. 633-653.

Hayes, C. W., 1895, Bauxite: U. S. Geol. Survey 16th Ann. Rept., pt. 3, pp. 547-597.

Hayes, C. W., 1902, U. S. Geol. Survey Geol. Atlas, Rome Folio (No. 78), 6 pp.

Hill, J. M., 1921, Bauxite and aluminum: Mineral Resources U. S., 1917, pp. 1-9.
Ingalls, W. R. (editor), 1906, Bauxite: Mineral Industry, during 1905, New York, pp. 46-51.

Julihn, C. E., 1933, Bauxite and aluminum: Minerals Yearbook, 1932-33, pp. 207-224.

Lewiecki, W. T., 1949, Investigation of the Hermitage bauxite district, Bartow and Floyd Counties, Georgia: U. S. Bur. Mines Rept. Inv. 4577, $10 \mathrm{pp}$.

McCallie, S. W., 1910, Preliminary report on the mineral resources of Georgia: Georgia Geol. Survey Bull. 23, 208 pp.

Morse, P. F., 1923, The bauxite deposits of Mississippi: Mississippi Geol. Survey Bull. 19, 208 pp.

Phalen, W. C., 1911, Bauxite and aluminum: Mineral Resources U. S., 1910, pp. 711-723.

Shearer, H. K., 1917, Notes on the bauxite deposits of north Georgia: Georgia Geol. Survey Bull. 31, Appendix B, pp. 325-329.

Spencer, J. W. W., 1893, The Paleozoic group; the geology of ten counties of northwestern Georgia: Georgia Geol. Survey, $406 \mathrm{pp}$.

Veatch, Otto, 1909, Second report on the clay deposits of Georgia: Georgia Geol. Survey Bull. 18, 453 pp.

Watson, T. L., 1904, A preliminary report on the bauxite deposits of Georgia: Georgia Geol. Survey Bull. 11, 169 pp. 
